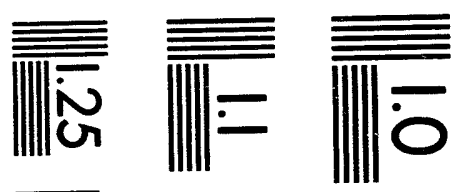

$$
\begin{aligned}
& \text { F }
\end{aligned}
$$

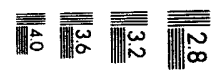

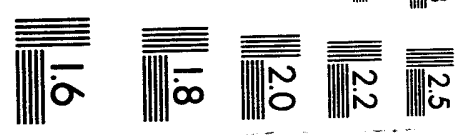



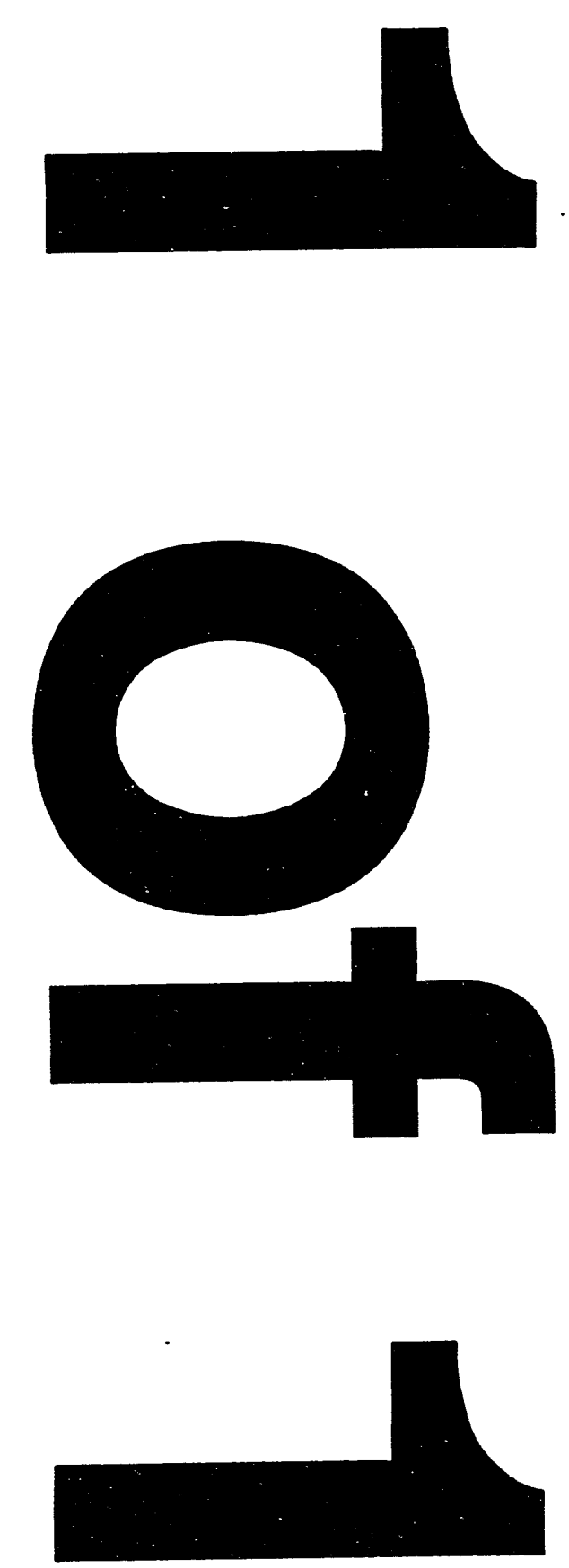


\section{YUCCA MOUNTAIN \\ SITE CHARACTERIZATION PROJECT}

\section{TECHNICAL DATA CATALOG (QUARTERLY SUPPLEMENT)}

DECEMBER 31, 1993 
TABLE OF CONTENTS

\section{PAGE}

INTRODUCTION . . . . . . . . . . . . . . . . . . . . . 1

ENVIRONMENTAL MONITORING AND MITIGATION PLAN . . . . . . . 4 METEOROLOGICAL MONITORING PLAN . . . . . . . . . . . . . 7

SITE CHARACTERIZATION PROGRAM BASELINE . . . . . . . . . . . 8

SITE CHARACTERIZATION PROGRAM BASELINE-PROTOTYPE . . . . . .54

SOCIOECONOMIC PLAN . . . . . . . . . . . . . . . . . . . . . . . . . .

$\begin{array}{ll}\text { APPENDIX A: } & \text { SITE CHARACTERIZATION PROGRAM BASELINE } \\ \text { ACTIVITY NUMBERS AND NAMES . . . . . A-1 }\end{array}$

APPENDIX B: GEOLOGIC AND ENGINEERING MATERIALS:

BIBLIOGRAPHY OF CHEMICAL SPECIES (GEMBOCHS)

SPECIES AND DATA TYPES . . . . . . . . B-1

$\begin{array}{ll}\text { APPENDIX C: } & \text { GEMBOCHS MODIFICATIONS AND ADDITIONS: } \\ & \text { lst QUARTER, FY 1994 . . . . . . . C-1 }\end{array}$

APPENDIX D: GEOGRAPHIC NODAL INFORMATION STUDY AND

EVALUATION SYSTEM (GENISES) ADDITIONS:

lst QUARTER, FY 1994 . . . . . . . . . . D-1 


\section{INTRODUCTION}

The March 21, 1993, Department of Energy (DOE)/Nuclear Regulatory Commission (NRC) Site-Specific Procedural Agreement for Geologic Repository Site Investigation and Characterization Program requires the DOE to develop and maintain a catalog of data which will be updated and provided to the NRC at least quarterly. This catalog is to include a description of the data; the time (date), place, and method of acquisition; and where it may be examined. The Yucca Mountain Site Characterization Project (YMP) Technical Data Catalog is published and distributed in accordance with the requirements of the site-Specific Agreement.

The YMP Technical Data Catalog is a report based on reference information contained in the YMP Automated Technical Data Tracking System (ATDT). The reference information is provided by Participants for data acquired or developed in support of the YMP. The Technical Data Catalog is updated quarterly and published in the month following the end of each quarter. A complete revision to the Catalog is published at the end of each fiscal year. Supplements to the end-of-year edition are published each quarter. These supplements provide information related to new data items not included in previous quarterly updates and data items affected by changes to previously published reference information. The Technical Data Catalog, dated september 30, 1993, should be retained as the baseline document for the supplements until the end-of-year revision is published and distributed in October 1994.

Requests for technical data referenced in the Data Catalog must be submitted in writing to the YMP Project Manager, Robert M. Nelson, Jr., at the following address:

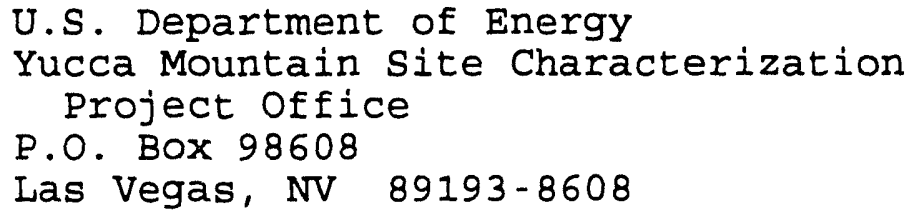

Requests should reference the Data Tracking Number (DTN) used to identify each data item included in the Data Catalog and should include the following information: the requester's name, organization, address, and telephone number; the scope of the data requested; a description of the intended use of the data; and any special format preferences. In response to specific requests, the YMP will provide the solicited technical data or information regarding where the data may be examined. 
The information contained in the Technical Data Catalog is organized by the governing plan under which the referenced technical data were acquired or developed. The applicable governing plans are identified in the Table of Contents. Site Characterization Program Baseline (SCPB) data items referenced in the Catalog are further grouped by SCPB Activity Number.

The Technical Data Catalog format includes the following information for each referenced data item:

(1) Data Tracking Number - Unique identifier for the referenced data item.

(2) Data Title/Description - A brief description of the referenced data item.

(3) Acquisition/Development Period - The date or range of dates during which the referenced data item was acquired or developed.

(4) Acquisition/Development Location - The field or laboratory location where the referenced data item was acquired or developed.

(NOTE: Locations are identified by unique names/identifiers or coordinates. Locations identified by coordirates may be expressed in geographic, Nevada state plane, or Universal Transverse Mercator (UTM). Nevada state plane coordinates are indicated by an "(N)" at the end of each coordinate; UTM coordinates are indicated by a "(U)".)

(5) Acquisition/Development Method - A brief description of the method used and/or the procedure followed to acquire or develop the referenced data item.

(6) Data Type - An "A" for acquired data or a "D" for developed data.

(7) Qualified - A "Y" fnr Yes or an "N" for No indicating whether or not the referenced data item was acquired or developed in accordance with an NRC accepted quality assurance program or qualified in accordance with appropriate YMP procedures.

(NOTE: Developed data items derived from other data sources are not classified as "Qualified" unless the data sources are also qualified.) 
(8) Data Location - A "P" indicates that the data reside in, and may be examined only at, a Participant Data Archive. A "T" indicates that the data are in the Technical Data Base (TDB) and may be examined there or at the Central Records Facility $(C R F)$. A "C" indicates that the data are in, and may be examined at, the CRF.

New data items, which were not included in a previous quarterly edition of the Technical Data Catalog, are identified by an asterisk (*) preceding the DTN. Changes to reference information published in a previous edition of the Catalog are identified by a double asterisk (**) preceding the DTN for each affected data item.

Appendix $A$ of this document lists the activity numbers and titles of all SCPB related data items referenced in the Catalog. Appendix B outlines the types of data that are available in the Geologic and Engineering Materials Bibliography of Chemical Species (GEMBOCHS) component of the TDB. Appendix C identifies additions or modifications that were incorporated into the GEMBOCHS data base during the current quarter. Appendix D identifies additions or modifications that were incorporated into the Geographic Nodal Information study and Evaluation System (GENISES) data base during the current quarter. 
**GS920300012548.001 DATA ON GROOND-WATER LEVELS AND SPRING FLOWS, INCLUDING WELL DEPTHS, CASING

02/01/90-05/09/91 DATA WERE COLLECTED USING STANDARD USGS

A N P ELOWS, INCLUDING WELL DEPTHS, CASING WELL AND SPRING LOCATIONS.

ACQN/DEVL LOCATION : $3600^{\prime} 00^{\prime \prime N} 11700^{\prime} 00^{\prime \prime}$; $3700^{\prime} 00^{\prime \prime N} 11600^{\prime} 00^{\prime \prime}$

$\star \star G S 920500012548.002$ DATA ON GROUND-WATER IEVELS AND SPRINGELOWS, INCLODING WELL DEPTHS, $05 / 10 / 91-12 / 31 / 91$ DATA WERE COLLECTE
HP-99, AND HP-166. CASING INFORMATION, DISCHARGE MEASUREMENTS, AND WELL AND SPRING LOCATIONS.

ACQN/DEVL LOCATION : $3600^{\circ} 00 \mathrm{~N} 11700^{\circ} 00^{\prime \prime}$; $3700^{\circ} 00^{\prime \prime N} 11600^{\circ} 00^{\prime \prime}$

$\star \star$ GS 920500012548.003 QUARTERLY DATA COLLECTED FOR FIRST QUARTER OF 1992 FOR REPORT "DATA ON

03/21/92-04/30/92 DSGS STANDARD METHODS GROOND-WATER LEVELS AND SPRINGFIOWS IN THE YUCCA MOUNTAIN REGION OF SOUTHERN NEVADA AND CALIFORNIA, JANUARY - MARCH 1992 .

ACQN/DEVL LOCATION : USGS WRD, LAS VEGAS

**GS920600012548.004 RAW DATA ON WATER-LEVEL MEASUREMENTS, QW AND SPRING DISCHARGES FOR JANUARY THRO MARCH 1992 .

ACQN/DEVL LOCATION : $360^{\circ} 0^{\prime} \mathrm{N} 11700^{\prime} \mathrm{W} ; 3700^{\prime} \mathrm{N} 11600^{\prime} \mathrm{W}$
01/01/92-03/31/92 DATA WERE COLLECTED USING HP-54,R0, WATER-FLOW MEASUREMENTS OSING WEIRS, FAND-HELD STEEI TAPES (IN VERTICAL BOREHOLES): HP-99, R1, INSTRUCTION FOR OPERATION OF A WELL SOUNDER FOR MEASURING WATER LEVELS; AND HP-166, RO, STREAM DISCHARGE MEASOREMENTS OSING A PYGMY METER. 
DATA TRACKING NO.

*GS931000121347.006 OUARTERLY DATA REPORT ON DATA OF GROUND-WATER LEVELS AND SPRING FLOWS IN THE YUCCA MOUNTAIN REGION FOR THE PERIOD JOLY THROUGH SEPTEMBER, 1993 DATA COLIECTED IN COOPERATION

. . DEPT
$07 / 01 / 93-10 / 21 / 93$

EN 7/1/93 TO

9/30/93 ACCORDING TO HP-26, R1, METHOD

CAI IBRATING WATER-LEVEL MEASUREMENT

CAITPMENT OSING THE REFERENCE STEEL TAPE EAP4 R1 WATER-FLOW MEASUREMENIS USING 90 DERRE V-NOTCH WEIRS, FLUMES AND BARRELS, DEG 1 RO OSE OF HAND-HELD STEEL TAPES (IN ( HP-99,RI, INSTROCTION FOR OPERATION OF A WELL SOUNDER FOR TEVELS; AND HP-166, R1 IEASURING WARE MEASUREMENTS USING A PYGMY CURRENT METER

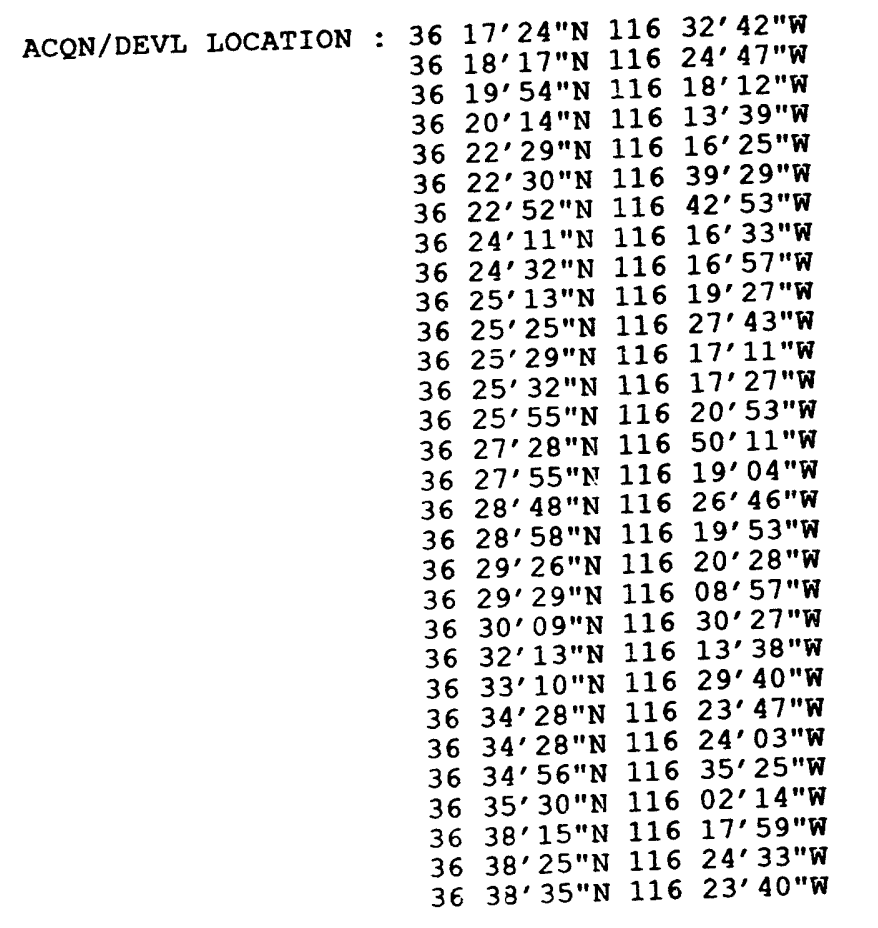


ENVIRONMENTAL MONITORING AND MITIGATION PLAN

DATA TRACKING NO.

$--$

TITLE/DESCRIPTION

ACQN/DEVL PERIOD

$3641,30 " \mathrm{~N} 11641,12 " \mathrm{~W}$

$3645^{\prime} 28^{\prime \prime N} 116 \quad 23^{\prime} 22$ "W

$3654^{\prime} 45^{\prime \prime N} 11638^{\prime} 39$ "W

$3655^{\prime} 20$ "N 116 37'03" W

$\mathrm{J}-11$

$\mathrm{J}-12$

$\mathrm{UE}-25$ WT 13

UE -25 WT 15

$\mathrm{OE}-25 \mathrm{VPW}$ VH-1

^GS931100121347.007

SELECTED GROUND-WATER DATA FOR YOCCA

MOUNTAIN REGION, SOUTHERN NEVADA AND

EASTERN CALIFORNIA, THROOGH DECEMBER

1992, BY R.J. LACAMERA AND C.L.

WESTENBURG.

ACQN/DEVL LOCATION : JSGS-WRD, LAS VEGAS, NV
T 2

D O L

I A $O$

F I C

T $\stackrel{F}{\mathbf{F}} \stackrel{\mathrm{T}}{\mathrm{T}}$

$\begin{array}{lll}T & F & T \\ Y & I & I\end{array}$

$\begin{array}{lll}Y & I & I \\ \text { P } & \text { E } & 0\end{array}$

\begin{tabular}{lll} 
E & D & N \\
\hline
\end{tabular}

ACQN/DEVL METHOD

06/01/93-09/30/93 DATA WAS CHECKED FOR ACCURACY AND

REASONABLENESS AND DEVELOPED ACCORDING TO REASONABLENESS AND DEVELOR 
DATA TRACKING NO.

TITLE/DESCRIPTION

ACQN/DEVI PERIOD

ACQN/DEVL METHOD

E D

*TM000000000001.044 AMBIENT AIR MONITORING REFORT, APRIL JUNE 1993

04/01/93-06/30/93 REFORMATTING OF DATA ACQUIRED BY DATALOGGERS

ACQN/DEVL LOCATION : YUCCA MOUNTAIN SITE AREA

*TM000000000001.045 AMBIENT AIR MONITORING DATA, JANOARY -

01/01/93-06/30/93 DATA ACOUIRED BY DATALOGGERS

A $Y P$ JUNE 1993

ACON/DEVL LOCATION : YUCCA MOUNTAIN SITE AREA

*TM000000000001.046 AMBIENT AIR MONITORING DATA, JU:Y -

07/01/93-09/30/93 DATA ACOJIRED BY DATALOGGERS

A Y P SEPTEMBER 1993

ACQN/DEVL LOCATION : YUCCA MOUNTAIN SITE AREA

*TM000000000001.047 AMBIENT AIR MONITORING REPORT, JULY SEPTEMBER 1993

07/01/93-09/30/93 REFORMATTING OF DATA ACQUIRED BY DATALOGGERS
Y P

ACQN/DEVL LOCATION : YUCCA MOUNTAIN SITE AREA 
DATA TRACKING NO.

TITLE/DESCRIPTIO

Activity - 8.3.1.2.1.2.1

*GS921108312121.001 SURFACE WATER DISCHARGE DATA INCLUDING COPIES OF RECORDER CHARTS AND PRECIPITATION DATA COLLECTED DURING THE 1992 WATER YEAR FOR YUCCA MOUNTAIN AND VICINITY, NYE COUNTY, NV, AND INYO COUNTY CA.

ACQN/DEVI LOCATI 37 30. J0"N $116 \quad 13,45 " \mathrm{~W}$

*GS930908312121.005 STREAMFLOW AND SELECTミD PRECIPITATION STREAMFLOW AND SELECTAIN ANE VICINITY, DATA FOR YUCCA MOUNATH ANC NYE COUNTY, NEVADA, BAUER, AND C.M. BY T.G. KANT

ACQN/DEVL LOCATION : JSGS, CARSON CITY, NV

/DEVL LOCATION : JSGS, CARSON CITY, NV
10/01/91-09/30/92 THESE DATA WERE COLLECTED UNDER HF\#'S HP-43, R1\&R2, INSTALL., OPER., \& INSPECT OF HP TWOTER-FLOW MEAS USING 90 DEG , FITMES \& BARRELS, HP-91, B R3, COLIECT \& RO R1 STREANI DISCHARGE SAMP MEAS USING A TYPE OF STREAMFLOW DISCHARGE HP-114, RO\&R1, EST OF PEAK STREAMELOW HP-115, R1, DETER OF PRT HP-116,R0\&R1 DISCHARGE USING CULVERTS, EXAMINE A METHOD TO INSTALL, OPER, \& EXAMI STIIL-WELI REC-STREAMF LOW GAGE THAT OSES A STRRI SYSTEM (WITH A CONT GRAPHIC RECORDER)' HP-117, RO\&R1, INSTALL, INSPECT \& MAINTS SCOUR CHAINS AT SIREAMF LOW GAGING SITES, HP-166, RO\&R1, STREAM DISCPARGE MEAS USING PEAK STREAMFIOW DISCHARGE BY THE INSTALI, OPER \& EXAM

INTREAMFLOW GAGE USING THE FLUID DATA G-II MANOMETER SYSTEM.

$1 / 01 / 92-08 / 27 / 93$ ACQUIRED DATA WERE COMPILED INTO AN OPEN ACQUIRED DATA WING CENERAI USGS REPORT FILE REPORT 
DATA TRACKING NO.

: $349^{\prime} 13^{\prime \prime N} 11623^{\prime} 52^{\prime \prime W}$ $3550,55^{\prime \prime N} 116,13,45 " \mathrm{~W}$ $3550^{\circ} 55^{\prime \prime N} 11613{ }^{\prime \prime} 45^{\prime \prime}$ $3611^{\prime} 48^{\prime \prime N} 11622^{\prime} 06^{\prime \prime} \mathrm{W}$ $3623,12 \mathrm{~N} 11625^{\prime}, 22^{\prime \prime W}$ $3626^{\prime} 09^{\prime \prime N} 11604,28^{\prime \prime} \mathrm{W}$

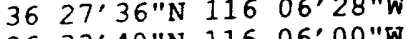
$363^{\prime} 43^{\prime} 40^{\prime \prime N} 116 \quad 06^{\prime} 00^{\prime \prime} \mathrm{W}$ $3634^{\prime} 00^{\prime \prime N} 11548^{\prime} 40^{\prime \prime} \mathrm{W}$ $3637^{\prime} 35 \mathrm{NN} 116 \quad 08^{\prime} 31$ "W $3640^{\prime} 18^{\prime \prime} \mathrm{N} 11626^{\prime} 03^{\prime \prime} \mathrm{W}$ $3641,08 " \mathrm{~N} 116 \quad 08^{\prime} 52^{\prime \prime} \mathrm{W}$ $3644^{\prime} 17^{\prime \prime N} 11613^{\prime} 58 " \mathrm{~W}$ $3646^{\prime} 06^{\prime \prime N} 11619^{\prime} 23^{\prime \prime} \mathrm{W}$ $3647^{\prime} 35^{\prime \prime N} 116 \quad 24^{\prime} 29^{\prime \prime} \mathrm{W}$ $3648^{\prime} 27 " \mathrm{~N} 116 \quad 05^{\prime} 41 " \mathrm{~W}$ $3648^{\prime} 27 " \mathrm{~N} 116 \quad 24^{\prime} 01$ " $3650^{\prime} 36^{\prime \prime N} 11626^{\prime} 26^{\prime \prime}$ $3650^{\prime} 57^{\prime \prime N} 116 \quad 27^{\prime} 07 " \mathrm{~W}$
OSGS TWRI'S: BOOK 3: CH.A1, A2, A3, A4, A5, A8; A Y P CH.A1; BOOK 8: CH.A2; AND USGS-WSP 2175. ALSO HP-40,R2, EST. PEAK-STREAMFL DISCHARGE BY SLOPE-CONVEYANCE: HE INSTAL., OPER. \& INSPECI. 2 TYPES

NON-RECORDING RAIN GAGES; HP-44,R3,

INSTAL. , OPER. \&EXAM. CREST-STAGE STRMFLOW GAGES: HP-45,R3, INSTAL. OPER. \&EXAM.

RECORDING STRMFLOW GAGE USING BUBBLE-GAGE STACOM MANOMETER SYSTEM; HP-91,R3,

COIIECT \& FIELD ANALY. SURFACE-WATER SAMPLES; HP-100,R1, STREAM DISCHG. MEAS. USING TYPE-AA PRICE CORRENT METER; HP-114, R1. EST. STRMFLOW DISCHG.; HP-115,R1, DI, ERT PEAK STRMFLOW DISCHG. USING CULVERTS: HP-116, R1\&R2, INSTAL.

COLVERT ME REORING STRMFLOW GAGE THAT OSES STILLING-WELL SYSTEM WITH CONT.

GRAPHIC RECORDER; HP-117, R2, INSTAL., INSPECT. \&MAINT. SCOUR CHAINS AT STRCHG. GAGING SITES; HPY CORRENT METER; HP-169, MEAS. USING PYGMY CTRMFLOW DISCHG. BY SLOPE-AREA. 
SITE CHARACTERIZATION PIAAN BASELINE

DATA TRACKING NO.

TITLE/DESCRIPTION

\section{ACON/DEVI, PERIOD}

$3651^{\prime} 06^{\prime \prime N} 116 \quad 25^{\prime} 44^{\prime \prime} \mathrm{W}$

$3651^{\prime} 16^{\prime \prime N} 116 \quad 27^{\prime} 07^{\prime \prime W}$

$3651.39 " \mathrm{~N} 116$ 26.08"W

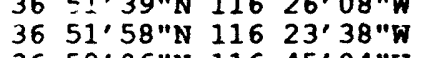

$3652^{\prime} 06^{\prime \prime N} 1164^{\prime} 04 " W$

$362^{\prime}, 06^{\prime \prime N} 116 \quad 45^{\prime} 34 " \mathrm{~W}$

$365^{\prime} 13^{\prime \prime N} 11622^{\prime} 50^{\prime \prime} \mathrm{W}$

365737 N 11643.09 "W

$3704^{\circ} 12^{\prime \prime N} 11620^{\circ} 23^{\prime \prime} \mathrm{N}$

$3704^{\prime} 19^{\prime \prime N} 116 \quad 20^{\circ} 50^{\prime \prime N}$

$3704.21 " N$ N $11620^{\circ} 50^{\prime \prime} \mathrm{W}$

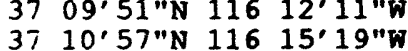

Act1vity - 8.3.1.2.1.3.2

*GS930908312132.018 WATER LEVEL MEASUREMENTS IN WELLS OF AMARGOSA DESERT PERFORMED BETWEEN $3 / 22 / 92 \& 9 / 30 / 93$. THE FOLLOWING LIST IDENTIFIES THE WELL, NUMBER OF

MEASUREMENTS IN 1992, \& NUMBER OF

MEASUREMENTS IN 1993: GS-1, 1,3 ; GS-3

STEEL, 0, 4; GS-3 PVC, 0, 5; GS-3 (FLP), 1, 0 ;

GS $-4,1,0$; GS $-5,1,0$; GS- $6,1,0$; GS-7, 1,0 ;

GS-9, 1, 0; GS-10,1,0; GS-12,1,1; GS-13,1

1; GS-14, 1, 1; GS-16,2,6; GS-17 PVC, 2, 6;

GS-18,1,2; GS-20 (FLP) , 0, 1; AM-1 STEEL, 1

3: AM-1 PVC, 1, 2; AM-2 STEEL, 1,$4 ; \mathrm{AM}-2$

PVC, 1, 4; BJ, 0, 3; BT-4, 1, 1; N25 E5 15, 3

3; JC-5, 1, 0; LC-262 PVC, 1, 3; LC-262

STEEL $, 1,3$; NA-2, 1, 1; NA-4 (BGWM-2), 0, 2;

NA-6 STEEL, 0,$2 ;$ NA-6 PVC, 0,$3 ;$ NA-7

STEEL, 5,4 ; NA-7 PVC, 5,$4 ; \mathrm{N}-8,0,2$; NA-9

STEEL, 1, 3; NA-9 PVC, 2, 5; NA-10 STEEL, 0

8: NA-10 PVC, 0,$8 ; \mathrm{S}-1$ STEEL, 1,$4 ; \mathrm{s}-1$

PVC, 1,$5 ; S-2,1,0 ;$ ST-1 STEEL, 0,$16 ;$ ST-2

STEEL, 0,14 ST-2 PVC, 0,25 ; WELL FL, 0,8 ;

WELL $5,0,2$; WELL-13,1, 0; CINDER IAKE B,

0,1 .

ACQN/DEVI LOCATION : $3600^{\circ} 00^{\prime \prime N ~} 11700^{\circ} 00^{\prime \prime}$ W $3700^{\circ} 00 " \mathrm{~N} 11600^{\circ} 00^{\prime \prime}$ 
DATA TRACKING NO.

TITLE/DESCRIPTION

ACQN/DEVL PERIOD

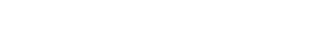

$\star$ GS931008312132.003

HYDROCHEMICAL DATA OF S.MAPLES COLLECTED FROM SMALL DIAMETER WEZ̈تS

ACQN/DEVL LOCATION : USGS NWQL, DENVER, CO

132.004 GROOND-WATER ALTITUDES AND WELL DATA, NYE COUNTY, NEVADA, ANI INYO COUNTY, NYE COUNTY, NEMPILED BY MAREK CIESNIK.

ACQN/DEVL LOCATION : USGS, DENVER, CO

*GS931108312132.019 SPREADSHEETS OF HYDROCHEMICAL ANALYSES, BY JOHN B. CZARNECKI: DATA FROM WELLS USW UZ-14 AND NA-7, NEVADA.

ACQN/DEVL LOCATION : USGS, DENVER, CO
$04 / 15 / 92-09 / 29 / 93$

STANDARD NWQL METHODS AND HP-23, R2 COITECTION AND FIELD ANALYSIS OF GRODND-WATER SAMPLES FROM SATURATED ZONE.

$02 / 10 / 91-12 / 15 / 92$

COMPILATION PRIMARILY FROM USGS NATIONAI COMP INFORMATION SYSTEM (NNIS) AND FROM OTHER PUBLISHED PAPERS.

$08 / 21 / 93-11 / 15 / 93$

PH AND SPECIFIC CONDOCTANCE DATA COMPILED, PH AND SPECIF SPREADSHEET AND PRESENTED AS POSTER.

10/01/91-09/30/92 DATA COLLECTED ACCORDING TO HP-99, R1 DATA COLIECTED ACCORDING OF A WELI A WELS, AND SOUNDER FOR MEASURING WATER LEVEL TAPES (IN HP-61, RO, USE OF HAND

Act1vity $-8 \cdot 3 \cdot 1 \cdot 2 \cdot 1 \cdot 3 \cdot 3$

$\begin{array}{ll}* \text { GS } 931208312133.002 & \text { DEPTH-TO-WATER DATA FOR UE-29A } \\ \text { COLLECTED IN WATER YEAR } 1992\end{array}$

ACON/DEVL LOCATION : UE-29 UZN-91

UE-29A \#1

$\mathrm{UE}-29 \mathrm{~A}$ \# 
DATA TRACKING No.

TITLE/DESCRIPTION

ACQN/DEVL PERIOD

*5931208312133.003 DEPTH-TO-WATER DATA FOR UE-29A \#1 AND YEAR 1993

ACON/DEVL LOCATION : UE-29 UZN \#91 UE-29A \#1
Activity - 8.3.1.2.2.3.1

* 9930808312231.005 SPATIAL VARIABILITY IN HYDROLOGIC PROPERTIES OF A VOLCANIC TUFF, BY J.D ISTOR, C.A.
$10 / 01 / 92-09 / 30 / 93$ DATA COLLECTED ACCORDING TO HP-99, R1, INSTROCTION FOR OPERATION OF A WELL SODNDER FOR MEASORING WATER IEVELS, AND HP-61, RO, USE OF HAND-HELD STEEL TAPES (IN VERTICAL BOREHOLES)

STANDARD I.AB DATA (POROSITY, BULK DENSITY, D N P PARTICLE DENSITY, SATURATED HYDRAOLIC PARTICLE DENSTTY, SORPTIVITY) WERE USED CONDUCTIVITY ANTATISTICAL AND

WITH STANDARD STATISTICAL AND GEOSTATISTICAL METHODS TO ENA OF PROPERTIES VARIABILITY AND CORRELAT

ACON/DEVI IOCATION : HYDROLOGIC RESEARCH FACILITY, AREA 25, MERCORY, NV

Activity - 8.3.1.2.2.7.1

*G930908312271.022 TRACER INJECTION DATA FROM UE-25 UZ\$16, UE-25 NRG\#1，UE-25 NRG\#3，UE-25 NRG\#2, UE-25 6 AND CORE SEALING DATA FROM USW NRG 16 OE-25 NRG\#1, AND OSW NRG-6.
$05 / 27 / 92-03 / 29 / 93$

DATA WERE COLLECTED IN ACCORDANCE WITH ME CONTAMINATION IN A DRY-DRILLED BOREHOLE; CO-160 R1 \& R1-M1, METHODS FOR ANALYSIS OF SAMPIFS FOR GAS COMPOSITION BY GAS CHROMOTOGRAPHY; HP-237T, RO, (SN-0030) CHRTODS TOR SEAIING UNSATURATED ZONE MER BORENT. CONTENT; AND HP 238T, ROS FOR DETERMINING INJECTION OF A TRACETION IN A DRY-DRILLED BOREHOLE.

ACON/DEVL LOCATION - UE-25 NRG\#1

UE-25 NRG\#2

UE -25 NRG\#3

UE-25 UZ 16 
DATA TRACKING NO.

Activity - 8.3.1.2.2.9.1

*GS930908312291.005 ESTIMATION OF ONSATURATED ZONE LIQUID WATER FLUX AT BOREHOLES UE-25 UZ \#4, WATER UZ 5 , USW UZ-7, AND USW UZ-13, YE-25 MOUNTAIN, NEVADA, FROM SATURATION YOCCA MOU POTENTIAL PROEILES BY EDWARD AND WATER POTENAN I. FLINT, AND R.W. M. KWICK

ACQN/DEVL LOCATION : USGS, DENVER, CO

Activity - 8.3.1.2.3.1.2

ARANSDUCER AND REIATED DATA. DATA IN THE FORM OF IOGBOOKS, STRIPCHARTS, AND ELECTRONIC DATA (AS STORED ON THE NWIS/ADAPS SYSTEM) .

ACQN/DEVL LOCATION : UE-25 WT $\$ 13$ UE-25 WT \#16 $\mathrm{UE}-25$ WT 3 $\mathrm{UE}-25$ WT $\# 6$ $\mathrm{UE}-25 \mathrm{~B} \# 1$ $\mathrm{UE}-25 \mathrm{P} \# 1$ USW G-3 USW $G-3$ USW $\mathrm{H}-1$ USW

OSW -4

USW $\mathrm{H}-5$

USW $\mathrm{H}-6$

USW WT -11
USW WT-2
09/01/92-05/30/93 ESTIMATES WERE MADE OF IIQUID FLOX AT 4 OSING MEASURED WATER POTENTIALS AND CONSTRUCTED SATORATION POTEN PROFILES ANDE HYDRAULIC CONDUCTV FUNCTIONS SATURATION GEND FIOX CALCOLATIONS PERFORMED USING AND FLUX CALCD
LOTOS $1-2-3$.

$01 / 01 / 92-12 / 31 / 92$

TRANSDUCER AND RELATED DATA COLLECTE USING TRANSDUCERS/21X SYSTEMS OR TRANSDOCER/DCP SYSTEMS. REEERENCE HP-196, R1, METHOD FOR COLLECTING WATER LEVEL DATA USING DATA COLLECTION PLATFORMS; HP METHOD FOR MONITORING WATER LEVEL CHANGES USING PRESSURE TRANSDUCERS AND PRESSURE TRANSMITTERS; HP-71,R0, METHOD FOR MONITORING WATER-LEVEL CHANGES USING CAMPBELI SCIENTIFIC $21 X$ MICROLOGGER. 
SITE CHARACTERIZATION PLAN BASELINE

DATA TRACKING NO.

TITLE/DESCRIPTION

ACQN/DEVL PERIOD

ACQN/DEVL METHOD

DATA COLLECTED ACCORDING TO HP-75, RI METHOD FOR MEASURING WATER IEV OSING REELED $(2600$ FT AND 2800 FT) STEEL TAPES.

07/01/93-10/01/93 DATA COLLECTED ACCORDING TO HP-60,R3, OSING PRESSURE TRANSDUCERS AND PRESSURE TRANSMITTERS, AND HP-196, RI, METHOD FOR COLLECTING WATER LEVEL DATA USING DATA COLLECTION PLATFORMS.
WATER-LEVEL DATA FROM THE PERIODI
NETWORK, 3RD QUARTER 1993 ONLY.

$$
\begin{aligned}
& \text { UE-25 WT } \\
& \text { UE-2 } 2 \text { C } 1 \\
& \text { UE-25C } 2 \\
& \text { OE- } 25 C \text { - } \\
& \text { USW } \mathrm{H}-3 \\
& \text { UST } \mathrm{H}-4 \\
& \text { USW } \mathrm{H}-5 \\
& \text { USW } \mathrm{H}-6 \\
& \text { USW } \mathrm{UZ}-14 \\
& \text { USW VH-1 } \\
& \text { USW WT-10 } \\
& \text { USW WT-2 } \\
& \text { USW WT-7 }
\end{aligned}
$$
1993 ONLY.

ACQN/DEVL LOCATION : UE-25 WT $\# 13$
*GS931008312312.023 RAW TRANSDUCER CALIBRATION DATA, WELLS
A Y P 
DATA TRACKING NO.

TITLE/DESCRIPTION

*GS931008312312.024 DEVELOPED WATER LEVEL DATA CONSISTING OF WATER-LEVEL WOEKSHEETS AND CALIBRATION WATER-LEVEL WOFKSHEETS FOR DATA COILECTED AT REGRESSIONS FOR DATA COLLECTED AT AREA, NEVADA. THIRD QUARTER ONLY, 1993. ACQN/DEVI, LOCATION : USGS, DENVER, CO

*GS931108312312.026 SCIENTIFIC NOTEBOOK SN-004G, SPECIFIC CAPACITY TESTS AT WELL OSW UZ-14. THE SCIENTIFIC NOTEBOOK CONTAINS RAW CHEMICAL ANALYSIS DATA AND WATER-LEVEL DATA.

ACQN/DEVL LOCATION : USW CZ-14

Activity - 8.3.1.2.3.2.3

*GS930908312323.003 HYDROCHEMICAL DATA FROM ANALYSES OF 23 WATER SAMPLES COLLECTED AT FIELD STATIONS: $\mathrm{J}-13 / 20, \mathrm{~J}-13 / 40, \mathrm{~J}-13 / 60$, ARMY 1/4.7, ARMY1/5.5, $\bar{u}-12 / 20, J-12 / 40$, $\mathrm{J}-12 / 60, \mathrm{VH}-1$, VIRGIN SPRING $8 / 19 / 92$, NEVARES SPRING 8/20/92, UZN\#91, JF-3, NEVAREZ SPRING $3 / 15 / 93$, MCLEAN SPRING (SALT CREEK), WOODCAMP SPRING,

STAININGER SPRING, VIRGIN SPRING

3/17/93, SARATOGA SPRING, GRAPEVINE

RANCH SPRING \#1, GRAPEVIN

\#3, KLARE SPRING, AND UZ-14-1282.

ACQN/DEVL LOCATION : OSGS NWQL, DENVER, CO

\section{ACQN/DEVL PERIOD}

ACQN/DEVL METHOD

10/01/93-10/07/93 WATER LEVEL DATA DEVELOPED OSING STANDARD STATISTICAI TECHNIQUES. 08/09/93-08/20/93 DATA COLLECTED ACCORDING TO ZHE PROCEDURES A Y P
OUTLINED IN THE SCIENTIFIC NOTEBOOK: STE WELL OZ-14. 
DATA TRACKING NO.

TITLE/DESCRIPTION

ACQN/DEVL PERIOD

ACQN/DEVL METHOD
Activity - 8.3.1.2.3.3.1

*GS921108312331.001 REVISED PRELIMINARY POTENTIOMETRIC SURFACE MAP OF YUCCA MOUNTAIN AND VICINITY, NEVADA, BY E.M. ERVIN, R.R. LUCKEY \& D.J. BORKHARDT

ACQN/DEVL LOCATION : USGS, DENVER, CO

*GS931008312331.001 SUMMARY OF REVISED POTENTIJMETRIC

SURFACE MAP, YUCCA MOUNTAIN AND

VICINITY NEVADA, BY E.M. ERVIN, R.R.

LUCKEY AND D.J. BURKHARJT

ACQN/DEVI LOCATION : USGS, DENVER, CO

Activity - 8.3.1.2.3.3.2

*S930808312332.003 POROSITIES OF CORE SAMPLES FROM BULLFROG POROR MOUNTAIN )

ACQN/DEVL LOCATION : HRF, AREA 25, NTS
09/01/91-08/31/92 WATER-LEVEL DATA WERE ANALYZED TO

DETERMINE POSSIBLE TRENDS IN THE

POTENTIOMETRIC SURFACE. MAP WAS PLOTTED

FROM WATER LEVEL DATA AND TREND ANALYSIS.

D N P

$08 / 31 / 92-11 / 30 / 92$ SUMMARY OF SOURCE DATA.

07/22/93-07/27/93 HP-229,R1 DETERMINATION OF WATER CONTENT A Y P TI , DETERMINATION OF WATER CONTEI ROCK SAMPLES 
Activity - 8.3.1.3.2.1.2

* LA000000000071.001 CHEMISTRY OF DIAGENETICALLY ALTERED TUFFS AT YUCCA MOUNTAIN

$01 / 01 / 82-08 / 30 / 86$ X-RAY FLUORESCENCE, ELECTRON MICROPROBE AND ATOMIC ABSORPTION SPECTROPHOTOMETRY

ACQN/DEVL LOCATION : LANL

*LA000000000071.002 CHEMISTRY OF DIAGENETICALIY ALTERED TUFFS AT A POTENTIAL NUCLEAR WASTE
REPOSITORY, YOCCA MOUNTAIN, NYE COUNTY, NEVADA

ACQN/DEVL LOCATION : LANL

Activity - 8.3.1.3.2.2.1

$\star \star$ IA000000000023.002 MINERALOGY AND CLINOPTIIOLITE R/AR RESULTS FROM YOCCA MOUNTAIN, NEVADA, USA; A POTENTIAL HIGE

$11 / 01 / 91-12 / 10 / 92$

SECONDARY MINERAIS SEPARATED BY SEDIMENTATION AND HEAVY LIQUIDS AND IDENTIFIED BY $X$-RAY DIFFRACTION AND SCANNIN ELECTR JTS OF CLINOPTILOLITES AND ARGON COME DETERMINED BY FLAME PTIVELY

SPECTROMETER, RESPCT APPARENT AGES (TWS-EES-1-10-91-4)

ACON/DEVI LOCATION - CASE WESTERN RESERVE UNIVERSITY CASE 
DATA TRACKING NO

TITLE/DESCRIPTION

ACQN/DEVL PERIOD

Activity - 8.3.1.3.2.2.2

$\star \star$ IA000000000017.002 DEHYDRATION AND REHYDRATION OF A TUFF VITROPHYRE

ACQN/DEVL LOCATION : LANL

*LA000000000060.001 THERMAL BEHAVIOR OF NATURAL ZEOIITES

ACQN/DEVL LOCATION : LANL

*IA000000000060.002 X-RAY POWDER DIFFRACTION DATA ON NATURAL ZEOLITES

*LA000000000068.001 ZEOLITE STABIIITY CONSTRAINTS ON CONCLUSIONS WERE REACHED ON POSSIBLE
ACQN/DEVL LOCATION : LANL RADIOACTIVE WASTE ISOLATION IN ZEOLITE-BEARING VOLCANIC ROCKS

04/15/80-04/15/81 A REVIEW OF THE IITERATURE OF THE STABILITY OF ZEOLITES WAS MADE AND CONSTRAINTS FOR RADIC ISOLATION.

D N T

THERMOGRAVIMETRIC ANALYSIS,

THERMOGRAVINETRIC INFRARED SPECTROGRAPHY,

EOURIER-TRANSFORM INERARED SPECTROGRAPHY,

11/01/92-06/30/93 A REVIEW OF THE LITERATURE ON THE STABILITY OF NATURAL ZEOLITES WAS MADE AND RESULTS OBTAINED BY THE LANL YMP

EFEORT WERE INCLODED. THESE YMP RESUITS ERE EITHER PREVIOUSLY PUBLISHED OR ARE IN PREPARATION FOR PUBLICATION.

\section{7/01/86-01/30/90 X-RAY DIFFRACTION DATA}

ACQN/DEVL LOCATION : LANI 
DATA TRACKING NO.

TITLE/DESCRIPTION

ACQN/DEVL PERIOD
EFFECTS OF EXCHANGEABLE CATION

COMPOSITION ON THE THERIMAL

EXPANSION/CONTRACTION OF CLINOPTILOLITE

ACQN/DEVL LOCATION : LANL

$\star \star$ IA000000000053.001 ACmINIDE (IV) AND ACTINIDE (VI) ACINIDE (IV) AND ACTINIDE (VI) PAS AND CARBONATE SPECIATION
NMR SPECTROSCOPIES.

Activity - 8.3.1.3.6.2.1

$\star \star L A 000000000034.002$ OF SORBING AND NON-SORBING RADIONUCLIDES.

ACON/DEVL LOCATION : LANL $\star$ LA000000000074.001

Activity - 8.3.1.3.5.1.1

ACQN/DEVL LOCATION : LANL

08/01/83-01/30/84 THE LATTICE PARAMETERS OF NATURAL AND CATION-EXCHANGED CLINOPTILOLITES WERE STODIED AS A FUNCTION OF IEMPERAT A HIGH-TEMPERATURE X-RAY POWDER DIFFRACTOMETER. (PAS) AND FOURIER-TRANSFORM

NOCLEARMAGNETIC RESONANCE (NMR) TO STUDY SPECTROSCOPY AAVE BETINIDE (IV) AND (VI) TONS. 
DATA TRACKING NO. TITLE/DESCRIPTIOI

Activity - 8.3.1.4.2.1.1

*GS930708314211.040 BEDROCK GEOLOGIC MAP OF THE LONE MOUNTATN PLOTON AREA ESMERALDA COUNTY NEVADA, BY FLORIAN MALIONADO.

ACQN/DEVL LOCATION : OSGS, DENVER, CO

*GS931008314211.034 PREIIMINARY LITHOLOGY WELL REPORT FOR UE-25WT\#14

ACON/DEVL LOCATION : USGS, DENVER, CO

GS931008314211.035 GRAPHICAL LITHOLOGIC LOG OF DRILI HOLE RE 8 (OE-25 RF *8), VERSION 1.0
ACON/DEVI PERIOD

ACQN/DEVL METHOD
01/01/83-01/01/84 MAP IS A COMPILATION OF FIELD DATA AND AER ISI A COMPIUATYSIS INTEGRATED WITH AERIAL PHOTO ANALYSIS INTE

PREVIOUSLY PUBLISHED MAJAR STROCTURAI

CHARACTERIZATION OF MAJOR STROCTORAL

FEATURES INCLUDE HOMOGENEITY, JOINT

FREQUENCY, JOINT AND BEDDING ATTITUDES,

DIKE TRENDS, AND AEROMAGNETICS. FOIATION

CHARACTERIZED BY MODAI ANALYS DIAGRAMS.

02/01/84-04/23/88 ANATYSIS OF CORE DRILLED PRIOR TO FEBRUARY A N P ¿84. GEOPHYSICAL LOGS WERE MADE FROM SCIENTIFIC OBSERVATIONS OF BIT COTTING SAMPIES.

08/01/93-09/02/93 THESE DATA WERE ACQUIRED FROM ANALYSES OF CORE OSING SN-0001, STRATIGRAPHIC STUDIES CROM SEOLOGIC DESCRIPTION OF CORE, BIT CUTTINGS, AND OUTCROP.

ACQN/DEVL LOCATION : SAMPLE MANAGEMENT FACILITY, NTS 
DATA TRACKING NO.

TITLE/DESCRIPTION

ACQN/DEVL PERIOD

$08 / 01 / 93-09 / 06 / 93$

GRAPHICAL LITHOLOGIC LOG OF BOREHOLE

$\star$ *GS931008314211.036 GRAPHICAL LITHOLOGIC LOG OF BORE
RF-3 (UE-25 RF 3 ), VERSION 1.0

ACON/DEVL LOCATION : SAMPLE MANAGEMENT FACILITY, NTS

$08 / 01 / 93-09 / 17 / 93$

GRAPHICAI LITHOLOGIC IOG OF BOREHOLE NRG -3 (UE-25 NRG \#3), VERSION 1.0

ACQN/DEVL LOCATION : SAMPLE MANAGEMENT FACILITY, NTS

*GS931008314211.038 GRAPHICAL LITHOLOGIC LOG OF BOREHOLE NRG-2A (OE-25 NRG\$2A), VERSION 1.0

$08 / 01 / 93-09 / 06 / 93$ ACON/DEVL LOCATION : SAIPLE MANAGEMENT FACILITY, NTS *GS931008314211.039 GRAPHICAL LITHOLOGIC LOG CF BOREHOLE NEVADA: VERSION 1.0

$08 / 01 / 93-09 / 24 / 93$

ACON/DEVL LOCATION : SAMPLE MANAGEMENT FACILITY, NTS
ACQN/DEVL METHOD
THESE DATA WERE ACQUIRED FROM ANALYSES OF CORE JSING SN-0OOI, STRATIGRAPHIC FROM GEOIOGIC DESCRIPTION OF CORE, BIT COT + INGS, AND OUTCROP

THESE DATA WERE ACQUIRED FROM ANALYSES OF TORE DSING SN-0001, STRATIGRAPHIC STUDIES FROM SEOLOGIC DESCRIPTION OF CORE, BIT CUTTINGS, AND OOTCROP.

THESE DATA WERE ACQUIRED FROM ANALYSES OF INE DSING SN-0001, STRATIGRAPHIC STUDIES CROM OSING SN DESCRIPTION OF CORE, BIT COTTINGS, AND OOTCROP.

HESE DATA WERE ACQUIRED FROM ANALYSES OF ORAPHIC STUDIES CORE USING SN-0001, STTION OF CORE, BIT CUTTINGS, AND OUTCROP. 
DATA TRACKING NO.

TITLE/DESCRIPTION

ACON/DEVL PERIOD

ACQN/DEVL METHOD

08/01/93-09/02/93 THESE DATA WERE ACOOIRED FROM ANALYSES OF CORE DSING SN-0001, STRATIGRAPHIC STUDIES FROM GEOLOGIC DESCRIPTION OF CORE, BIT

COTTINGS, AND OUTCROP.

ACQN/DEVL LOCATION : SAMPLE MANAGEMENT FACILITY, NTS

*GS931108314211.041 GRAPHICAI IITHOLOGIC LOG OF BOREHOLE GRAPHICAL LITHOLOGIC IOG OUCA MOUNTAIN NRG-2B (UE-25 NRG $2 B)$

$08 / 01 / 93-10 / 01 / 93$

ACQN/DEVL LOCATION : SAMPLE MANAGEMENT FACILITY, NTS

* GS931108314211.042 GRAPHICAL IITHOLOGIC LOG OF BOREHOLE NRG-4 (UE-25 NRG\#4), VERSION 1.0

$08 / 01 / 93-09 / 30 / 93$

ACON/DEVL LOCATION : SAMPLE MANAGEMENT FACILITY, NTS

*GS931108314211.043 GRAPHICAL LITHOLOGIC LOG OF BOREHOLE NRG -5 (UE -25 NRG $\$ 5)$, VERSION 1.0

$08 / 01 / 93-09 / 30 / 93$

A. N/DEVI LOCATION : SAMPLE MANAGEMENT FACILITY, NTS
THESE DATA WERE ACQUIRED FROM ANALYSES OF CORE USING SN-OOOI, STRATIGRAI FROM GEOLOGIC DESCRIPTION OF CORE, BIT COTTINGS, AND OUTCROP.

THESE DATA WERE ACOUIRED FROM ANALYSES OF THESE DATA WERE CORE USING SN DESCRIPTION OF CORE, BIT CUTTINGS, AND OUTCROP. CORE ISING SN-0001, STRATIGRAPHIC STUDIES CROM OSIOIG SIC DESCRIPTION OF CORE, BIT FROM GEOLOGIC DESCRIPTIO
THESE DATA WERE ACOUIRED FROM ANALYSES OF 
DATA TRACKING NO.

\section{$\star$ GS931108314211.044} SUMMARY LITHOLOGIC DESCRIPTION OF THE UPPER TIVA CANYON FORMATION AND TOFE UNIT " $X$ " IN THE NORTH RAMP THOMAS MOYER, JEFFREY GESLIN AND DAVID BUESCH

ACQN/DEVL LOCATION : USGS, LAS VEGAS, NV DE-25 NRG 1 , VERSION 1 .

ACON/DEVL LOCATION : SAMPLE MANAGEMENT FACILITY, NTS

$\star$ GS 931208314211.047 GRAPHICAL LITHOLOGIC LOG OF BOREHOLE USW OZ-16, VERSION 1.0
^GS931208314211.046 GRAPHICAI LITHOLOGIC LOG OF BOREHOLE
08/01/93-09/17/93 EXAMINATION OF GEOLOGIC DESCRIPTION OF CORE INFORMATION COLLECTED IN FY' 93 TO SUMMARIZE AND PROVIDE
ACCOMPANY SOURCE DATA.

THESE DATA WERE ACOUIRED FROM ANALYSES OF CORE USING SN-0001, STRATIGRAPHIC STUDIES FROM GEOLOGIC DESCRIPTION OF CORE, BIT CUTTINGS, AND OUTCROP.

\section{A Y P}

01/01/93-11/18/93 THESE DATA WERE ACQUIRED FROM ANALYSES OF THE DSTA SN-0001, STRATIGRAPHIC STUDIES CORE OSIOG SN DESCRIPTION OF CORE, BIT CUTTINGS, AND OUTCROP.

ACQN/DEVL LOCATION : SAMPLE MANAGEMENT FACILITY, NTS

$\star$ GS931208314211.048 GRAPHICAL LITHOLOGIC LOG OE BOREHOLE USW

$01 / 01 / 93-11 / 18 / 93$ OZ-14, VERSION 1.0

ACON/DEVI LOCATION : SAMPLE MANAGEMENT FACILITY, NTS THESE DATA WERE ACQUIRED FROM ANALYSES OF CORE USING SN-0001, STRAT OF CORE, BIT COTTINGS, AND OUTCROP. 
DATA TRACKING NO.

TITLE/DESCRIPTION

ACQN/DEVL PERIOD

ACQN/DEVL METHOD

MTCROSCOPIC OBSERVATIONS MACROSCCPIC AND MICROSCOPIC OBSERV INCLUDING PHENOCRYST ASSEMBLAGES, DEPOSITION TEXTURES AND STRUCTURES, ZONES OF WELDING, ZONES OF CRYSTALLIZATION, AND SURFACE ROUGHNESS AND ORIENTATION OF FRACTURES

LITHOSTPNTIGRAPHIC UNITS EXPOSED ATSCH YUCCA MOUNTAIN, NEVADA, BY AND J. GESLIN.

ACON/DEVL LOCATION : USGS, LAS VEGAS, NV

*GS931208314211.050 INTEGRATED GEOLOGY ALONG THE NORTH RAMP INPLOPATORY STUDIES FACILITY, YUCCA MOUNTAIN NEVADA, BY D.C. BUESCH, R.P. MOUNAT, NEMÁ, AND R.W. SPENGLER ACON/DEVL LOCATION : USGS, LAS VEGAS, NV

ॠGS931208314211.051 X-RAY FLUORF SCENCE ELEMENTAL X-RAY FLUORF SCENCE ELENENTAL

ACON/DEVL LOCATION : USISS, DENVER, CO
09/15/93-12/20/93 ANALYSIS AND INTEGPATION OF SURFACE IOGS OF CORE FROM DRILI HOLES, AND SURFACE AND DOWN HOLE GEOPHYSICS.

03/09/93-03/14/93 OSGS TECHNICAL PROCEDURE GCP-25,R0, OSGS TECHNICAL PROCEDUREAL COMPOSITION BY DETERMINATION OF CHEMICAL COMPOSITION SPECTROMETRY 
DATA TRACKING NO.

TITLE/DESCRIPTION

Activity - 8.3.1.4.2.1.2

¿GS930808314212.010 GRAVITY AND MAGNETIC DATA OF MIDWAY VALLEY, SOUTHWEST NEVADA, BY D.A. PONCE V.E. LANGENHEIM, AND R.F. SIKORA

ACON/DEVL LOCATION : USGS, MENLO PARK, CA

*GS930808314212.011 GRAVITY AND MAGNETIC STUDY OF YUCCA WASH SOUTHWEST NEVADA, BY V.E. WASH, SOUTHEST NEVANE, H.W. OLIVER, AND R.F. SIKORA

ACQN/DEVL LOCATION : USGS, MENLO YARK, CA

Activity $-8 \cdot 3 \cdot 1 \cdot 4 \cdot 2 \cdot 1 \cdot 3$

**GS930708314213.009 MAGNETIC SUSCEPTIBILITY (MS_SI) MAGNETIC FIEID (TOTAL FIELD IM, HORIZONTAL FIELD HM, VERTICAL FIELD LOGS. SUSCEPTIBILITY REPORTED I MICRO-SI UNITS, MAGNETIC F

ACON/DEVL LOCATION : NRG-6 USW UZ -16

*GS931108314213.010 WATER PERMEABILITY AND SELECTED WATER PERMEABISITY AND SELECTED IES FROM PROPERTIES MEASTA USW GU-3;G-3 AND USW THE YUCCA ANDERSON.

ACQN/DEVL LOCATION : USGS, DENVER, CO
ACON/DEVL PERIOD

ACQN/DEVL METHOD

$09 / 30 / 92-08 / 30 / 93$ DATA

09/30/92-08/30/93 COMPILATION AND ANALYSIS OF THE SOURCE
$04 / 14 / 93-06 / 26 / 93$ JSGS TECHNICAL PROCEDURES GPP-15, R1 AND GPP-17,R1: MAGNETIC SUSCEPTIBILITY BOREHOLE LOGGING OPERATIONS AND

$01 / 01 / 91-10 / 15 / 93$ CORE SAMPLES FROM THE YM-OSW GO-3/USW G-3 AND RESISTIVITY, AND WATER PERMEABILITY TO DETERMINE RELATIVE LEVELS OF FLUID CONDUCTIVITY ATTRIBUTABLE TO THE MATRIX OF THE TOFFS ENCOONTERED WITHIN THE RESPECTIVE BOREHOLES. 
DATA TRACKING NO.

TITI:E/DESCRIPTION

ACON/DEVL PERIOD SATURATION LEVELS AND TRENDS IN THE UNSATURATED ZONE, YOCCA MOUNTAIN, NEVADA, BY P. NELSON.

ACON/DEVI LOCATION : USGS, DENVER, CO Activity - 8.3.1.4.2.2

ANSAND877081A0.000 SAND87-7081A: "STYLES OF EXTENSION IN TITE REGION, SOUTHERN WALKER LANE BELT; AN INTEGRATION OF VOLCANO-TECTONIC AND DETACFMENT FAOLT MODELS"

ACON/DEVL LOCATION : SNL

Act1vity - 8.3.1.4.2.2.1

*GS931008314221.011 STRUCTURAI CHARACTER OF THE NORTHERN TECMNT OF THE PAINTBRUSH CANYON FAOLT, YOCCA MOUNTAIN, NEVADA, BY R.P.

YUCCA MOUNAN', $R$. SPENGLER

ACQN/DEVI LOCATION : USGS, DENVER, CO
$08 / 01 / 93-12 / 15 / 93$

CALIPER, DENSITY, AND EPITHERMAL NEUTRON LOGS WERE EXAMINED; WATER CONTENT AND LOGS DOR TTY 15 "WT" BOREHOLES DRILLED TO THE DERTH OE THE STATIC WATER LEVEL ARE PRESENTED.

DETICAL INFORMATION, SUPPORTED D N C BY GEOPHYSICAL DATA AND DRILI HOLES INDICATES THAT SEVERAL DEFORMATIONAL STYLES CHARACTERIZE THE WALKER LANE BE OF THE SOUTH-CENTRAL GREAT BASIN AND NEVADA TEST SITE RE SAND87-7081A FOR A DETAILED DESCRIPTION).

05/01/93-09/30/93 TECHNICAL PROCEDURE GP-01,R2 GEOLOGIC MAPPING. 
DATA TRACKING NO.

TITLE/DESCRIPTION

ACQN/DEVL PERIOD

ACQN/DEVI METHOD

\section{DATA TRACKING WO}

$\star$ GS931208314221.012 FUIT ATTITUDE DATA OF THE PAINTBRUSH CANYON FAULT SYSTEM.

ACON/DEVI LOCATION : N770270(N) E570900(N)

* 931208314221.013 FIEID DATA AND PETRCGRAPHIC DATA FOR FEDDE TUFE IN THE RHYOLITE OF CALICO WELDED, IN FORTYMILE WASH.

ACQN/DEVI LOCATION : JSGS, DENIER, CO

* 9931208314221.014 PETROGRAPHIC EVIDENCE FOR A WELDED TUFF IN THE RYHOLITE OF CALICO HILLS, BY DICKERSON, R P AND HUNTER $=\mathrm{W}$

ACQN/DEVL LOCATION : JSGS, JENVER, CO

*GS931208314221.015 PHOTOMICROGRAPHS OF THIN SECTIONS FROM ANTLER RIDGE

A.CQN/DEVL LOCATION : USGS, DENVER, CO

*GS931208314221016 PETROGRAPHIC AND GEOCHEMICAL

CEARACTERISTICS OF TIVA CANYON TUEF, CHARACTERISTICS OF TIVA CANYN, NEVADA, BY ANTLER RIDGE, YUCCA MU, JR., B.L. WIDMAN F. SINGER, F. J. BYER

ACQN/DEVL LOCATION : USGS, DENTER, CO
05/01/92-11/05/93 NWM-USGS GP-01, R2, GEOLOGIC MAPPING.

A Y P

; $N 793000(N) \quad E 579000(N)$

04/01/93-12/03/93 TECHNICAL PROCEDURE GP-01,R2, GEOLOGIC MAPPING, AND GP-18,R1, PETROGRAPHIC ANAIYSIS OF VOLCANIC ROCKS.

09/01/93-12/31/93 REPORT WAS DEVELOPED BY ANALYZING AND INTERPRETING FIELD MAPPING AND DATA.

05/01/93-12/06/93 GP-18,R1, PETROGRAPHIC ANALYSIS OF VOLCANIC ROCKS

DXAMINATION OF AN DTAILED PETROGRAPHIC EXAMINATION OF AN ANTLER RIDGE THIN SECTION SUITE DES RELATED POST DEPOSITIONAL MINERAL TUFF WELDED TO COLLING OF TIVA CANYO DEVITRIFICATION AND VAPOR PHASE MINERALOGY) AIDED BY CHEMICAL ANALYSIS 
DATA TRACKING NO.

TITLE/DESCRIPTIO

ACON/DEVL PERTOD

ACQN/DEVL METHOD

A Y P

*GS931283117452.005 GEOLOGIC MAPEING IN CRATER FLAT, IN AND AROUND FOUR 7.5 MINUTE QUADRANGLES: 1

EAST OF BEATTY MOCNTAIN, 2) BEE.TTY

MOUNTAIN , 3) CRATER FLAT, 4) BIG DUNE.

ACON/DEVI LOCATION : $3652^{\prime} 30 " \mathrm{~N} 11637,30$ "W; $3700^{\prime} 00^{\prime \prime} \mathrm{N} 11630^{\prime} 00^{\prime \prime} \mathrm{W}$

Activity - 8.3.1.4.2.2.2

*S931008314222.006 FRACTURE DATA FOR P2001 PAVEMENT AT FRAN FRACTURE DATA FOR P $02 / 09 / 93,3 / 1 \epsilon-17 / 93$, AND RIDGE,

02/09/93-04/09/93 TECHNICAL PROCEDORE NWM-USGS GP-12,R1, TECHNICAL PROCEDURE M PAVEMENTS, OUTCROPS, AND ALONG TRAVERSES.

ACQN/DEVL LOCATION : P2001 PAVEMENT

Activity $-8.3 \cdot 1 \cdot 4 \cdot 2 \cdot 2 \cdot 4$

*GS931008314224.006 GEOLOGIC FIELD MAPPING NOTEBOOKS AND LINE SURVEY COMPII

04/14/93-09/10/93 SN-0041,R0, UNDERGROUND MAPPING OF THE NORTH RAMP STARTER TUNNEL AND APPURTENANCES

ACON/DEVL LOCATION : NORTH RAMP OF ESF, AREA 25, NTS

$\star G S 931008314224.007$

FULL-PERIPHERY MAPS, NORTH RAMF OF THE EXPI PERTPY STUDIES FACILITY, THROUGH EXPOBER, 1993.

$04 / 14 / 93-09 / 10 / 93$

SN-0041, RO, UNDERGROOND MAPPING OF THE NORTH RAMP STARTER TUNNEL AND

APPURTENANCES

ACON/DEVL LOCATION : NORTH RAMP OF ESE, AREA 25, NTS 
DATA TRACKING NO.

TITLE/DESCRIPTION

ACQN/DEVL PERIOD

ACQN/DEVL METHOD

01/01/93-12/09/93 SP-13,R1, VSP AND CROSSHOLE TOMOGRAPHIC SURVEYS
*GS931208314225.001 VSP DATA FROM USW NRG-6 AND USW WT-2

ACQN/DEVL IOCATION :

N750586.96610(N) E562111.65543(N) N760592.39532(N) E562159.11495(N)

N760596.53374(N) E562060.00276(N)

N760613.91922 (N) E562209.96883(N)

N760617.72844(N) E562016.83945(N)

N760635.22251 (N) E561971.61496(N)

N760643.42035(N) E562248.65178(N)

N750660.54000 (N) E561923.56000 (N)

N760674.34866(N) E562286.07975(N)

N7507C8.62988(N) E562322.38096(N)

N7507C 9.03529 (N) E561861.06022(N)

N750743.42170(N) E562356.79929(N)

N750768.46645 (N) E562406.87925 (N)

N7 50789.85461 (N) E562446.05127 (N)

$\mathrm{N} 750802.13060(\mathrm{~N})$ E562490.77385(N)

N760304.52429 (N) E562897.30774(N)

N760812.43019(N) E562540.73690(N)

N750817.82754 (N) E562590.35809(N)

N760819.13400(N) E562836.77942(N)

N760822.32512(N) E562640.04954(N)

N760823.01716(N) E562686.90466(N)

N7508 $23.72724(N) \quad E 562787.52201(N)$

N760824.51338(N) E562739.71504(N)

N766067.45545(N) E564351.69944(N)

N766649.33809(N) E564161.39669(N)

N756726.02468(N) E564186.92569(N)

N766820.34544(N) E564552.00920(N) 
DATA TRACKING NO.

TITLE/DESCRIPTION

ACON/DEVI PERTOD

Activity - 8.3.1.4.3.1.1

TM0000000000CL.003 PRELIMINARY COMPOSITE BOREHOLE LOG AND

PRELIMINARY COMPOSITERIES EOR

$06 / 17 / 93-07 / 21 / 93$ SHIFT DRILIII
UE -25 NRG 4

ACQN/DEVI LOCATION : N767080.2(N) E566820.0(N)

GRAPHICAL REPRESENTATION OF BOREHOLES

ITHOLOGY AND RELATED DRILLING

LITHOLOGY AND RELAR RUN INTERVALS PROVIDED

INF TMA SION CRTIING SUMMARIES.

NWM-USGS GCP-16,R3 CARBONATE CARBON AND

Activity - 8.3.1.5.1.2.1

$\star$ GS 931208315121.002 STABLE ISOTOPE ANALYSES OF GASTROPODS, 10/93-11/93.

OXYGEN ISOTOPE ANALYSES.

ACON/DEVL LOCATION : USGS, JENVER, CO

EVAIDATION OF THE USE OF ISOT ANALYSIS OF MOLLUSCS WITHIN A SAMPLE TO

*GS931208315121.003 MOLLUSCS AS CLIMATE INDICATORS PRELIMINARY RESULTS OF STABLE ISOTOPE FORES'IER, AND $T$. MCCONNAUGHE

DETERMINE THE CLIMATE VARIAB TIMESPAN

ACON/DEVL LOCATION : DESERT RESEARCH INSTITUTE, RENO, NV 
DATA TRACKING NO.

Activity - 8.3.1.5.1.2.2

*GS 931208315122.003 FOSSII OSTRACODE SPECIMENS FROM MARSH DEPOSITS IN LAS VEGAS A-IEY

ACQN/DEVL LOCATION : USGS, DENVER, CO

* GS931208315122,004 LEVELS AND STYLES OF PRECIPITATION DURING THE LATE GLACIAL IN SOUTHERN NEVADA RECONSTRUCTED FROM THE FOSSIL OSTRACODE RECORD, BY R.M. FORESTER AND A.J. SMITH.

ACON/DEVL LOCATION : USGS, DENVER, CO

Activity - 8.3.1.5.1.4.1

*GS931008315141.006 SEASONAL VARIATIONS OF CARBON DiOXIDE CONCENTRATIONS IN STONY, COARSE-TEXTURED CONCERT SOILS OF SOUTHERN NEVADA, U.S.A., DESERT TERHUNE AND J.W. HARDEN

ACQN/DEVL LOCATION : USGS, MENLO PARK, CA
01/20/93-12/01/93 SAMPLE COLLECTION FOLLOWED GP-27, R2, TRENCH WALL AND NATURAL OUTCROP SAMPLING FOR COORDINATED STUDIES, SAMPLE PROCESSING FOLLOWED HP-78, R1, NONMARINE CALCEREOUS MICROFOSSIL SAMPLE PREPARATION AND DATA ACQUISITION.

9/30/93-11/30/93 THE OSTRACODV CONTENTS OF SEVERAL SAMPIES THE OSTRACODE: CONTENTS OF SEVERAL SAME COLLECTED FRU NEAR TTE (QUADE 1986, QUADE NEAR THTT 1989) WHERE THE UNIT D/E AND PRATY IS ABOOT 13 TO $14 \mathrm{KA}$, WERE OSED BOONDARY IS ABI INARY PALEOHYDROLOGICAL TO PROVIDE PRELIMINARY PALEOHYDR.

01/01/86-07/07/87 SAMPLES WERE ANALYZED BY GAS CHROMOTOGRAPHY TO MEASURE CO2 CONCENTRATION. AV ATMOSPHERE SAMPLES SUBTRACTED FROMATION WAS AREA OF A KNOWN STANDARD CONCENTRATI NHE USED TO OBTAIN THE CONSTANT BY WHCH THE PEAK AREAS WERE CONVERTED INTO PERCENTAGE OF CO2.
A Y P

to


SITE CHARACTERIZATION PLAN BASELINE

DATA TRACKING NO. TITLE/DESCRIPTION

Activity - 8.3.1.5.1.4.3

$\star$ הS931108315143.001 THERMOLUMINESCENCE AGE DATING FOR MIDWAY VALLEY TRENCHES $4,5 A$, AND I $4 D$,

STAGECOACH ROAN TRENCH 1 , AND BUSTED

BUTTE WALL 4

ACQN/DEVL LOCATION : TL LAB, USGS, DENVER

Activity - 8.3.1.5.2.1.3

*GS930908315213.020 USGS NWQL WATER CHEMISTRIES DERIVED FROM SAMPLES COLLECTED 6-1-93 TO 6-E-93.

$06 / 01 / 93-09 / 12 / 93$

ACON/DEVL LOCATION : USGS NWQL, ARVADA, CO

*GS930908315213.021 PHYSICAL WATER PROPERTIES OBTAINED IN

FIELD DURING SAMPING TRIFS FROM 1988
THROUGH $5 / 2 / 89$. DATA RECORDED ON SAMPLE COLLECTION FORMS.

01/01/88-05/02/89 YMP-USGS TECHNICAL PROCEDURES HP-59,R0, METHOD FOR CALIBRATING DIGITAI THERMOMETERS; HP-23, RO, COLLECTION AND FIELD ANALYSIS OF GROUND-WATER SAMPLES FROM SATURATED ZONE; AND HP-91,R0, COLLECTION AND FIELD ANALYSIS OF SURFACE-WATER SAMPLES
STANDARD USGS NATIONAL WATER QOALITY LAB METHODS AND PROCEDURES.

ACON/DEVL LOCATION : $3500^{\circ} 00 \mathrm{~N} 11800^{\prime} 00^{\prime \prime} \mathrm{W} ; 3800^{\circ} 00^{\prime \prime N} 11500^{\circ} 00^{\prime \prime} \mathrm{F}$ 
Activity - 8.3.1.5.2.1.4

*GS930908315214.015 METEOROLOGICAL DATA FROH A STATION AT ORGAN PIPE CACTOS NAT' I MONUMEN'

ARIZONA: BAROMETRIC PRESSURE, SOLAR RADIATION, AIR TEMPERATURE, WIND SPEED WIND DIRECTION.

ACON/DEVL LOCATION : 32 05'24"' $11244^{\prime} 21^{\prime \prime}$ h

$\star$ ॠS930908315214.030 CHEMICAL ANALYSIS OF SURFACE-WATER, CHEMICAL ANATYSIS OF SOREACE-WATER, SPRING, AND PRECIPITATIOND STENART CREEK COLLECTED FROM KAWICH AND BASINS FROM FEBRUARY 19 SEPTEMBER, 1992. SAMPLES ANAPS ANIONS, CATIONS, STABI PHYSICAL PARAMETERS.

ACQN/DEVL LOCATION : USGS CENTRAL LAB, ARVADA, CO

FIELD NOTES FOR THE ANALOG RECHARGE PROJECT EROM JUNE, 1992, TO SEPTEMBER, 1992
$06 / 09 / 92-09 / 30 / 92$ DATA ACQUIRED USING THE FOLLOWING OF ATM PROCEDURES: HP-16, R3, COLD O-18 ANALYSIS: PRECIP SAMPLES FIOW MMT USING WEIRS, HP-54, R1, WATER-FLOW MAT OSING WEIRS, FLUMES, AND BARRELS: HP-57,R1, 3 WATER-LEVEL RECORDERS: HPCOLLECTION AND ANALYSIS OF SURFACE-WATEE SAMPLES; HP-97, R1, MIT OF TEMP AND RH OSING A CSI 207 PROBE; HP-165, R0,

MEASURING SNOW WATER CONTENT; HP-166, RI, STREAM DISCHARGE MEASUREMENT USING A PYGMY CURRENT METER; HP-167,R0, PRECIP MTT USING CORRIFORT WI IGHING RAIN GAGE; HP-168, R0 A BE ENERGY FLOX DENSITY BY A

PYRANOMETER: HP-170,R1, MEASURING TEMP OSING A CSI 107 PROBE: HP-171,R1, LOW TENSION VADOSE MOISTOFE SAMPLING; HP-172, TENSTI USING A TEN-TURN POT: RO, WATER HP-184, R1, COR CHEMICAL ANALYSIS; AND HP-198, RI 
SITE CHARACTERIZATION PLAN BASELINE

DATA TRACKING NO.

TITLE/DESCRIPTION

ACQN/DEVI PERIOD

ACON/DEVL METHOD

AN RM YOUNG WIND MONITOR.
*GS931008315214.032 METEOROLOGICAL, DISCHARGE, AND WATER-QUALITY DATA FOR 1992 FROM TWO BASINS IN CENTRAL NEVADA, BY P.W. MCKINLEY AND THOMAS OLIVER

ACQN/DEVL LOCATION : USGS, DENVER, CO
12/01/92-10/08/93 DATA WERE DEVELOPED INTO DAILY VALUE TABLES DSING THE NATIONAL WATER

INFORMATION SYSTEM (NWIS) DATABASE.

MISSING DATA WERE ESTIMATED BY REGRESSION

TO OTHER METEOROLOGICAL DATA OSING MINITAB RELEASE 7.2 OR WERE ESTIMATED BY INTERPOLATION.

Activity $-8.3 \cdot 1 \cdot 5 \cdot 2 \cdot 1.5$

**GS910608315215.010 TABLE OF STRONTIUM ISOTOPE DATA IN SUPPORT OF PUBLICATION.

ACQN/DEVL LOCATION : CRATER FLAT, NTS

*GS930908315215.027 86SR/B7SR MASS SPECTROMETER DATA FOR SAMPLES RUN $3 / 2 / 92-11 / 18 / 92$.

03/02/92-11/18/92 GCP-12,R3, RB-SR ISOTOPE GEOCHEMISTRY.

*GS931008315215 028 SPECIMEN DESCRIPTIONS WITH PHOTOS FOR SPECIMEN DESCRIPTIONS WITH PHOTOS FOR 1993.

ACQN/DEVI LOCATION : USGS, DENVER, CO
04/10/93-09/30/93 USGS TECH PROCEDURE GCP-02,R2, LABELING, IDENTIFICATION, AND CONTROL OF SAMPLES FOR GEOCHEMISTRY \& ISOTOPE GEOLOGY. 
DATA TRACKING NO.

TITLE/DESCRIPTION

CARBON AND OXYGEN ISOTORE ANALYSES OF CAICITE AND SOIL CARBONARE OUTCROPS, MAY' $89-$ OCT. ' 3 .

ACQN/DEVL LOCATION : JSGS, DENVER, CO *GS931108315215.031 STRONTIUM ISOTOPES IN CARBONATE DEPOSITS AT CRATER ELATERA ANJ J.S. STUCKLESS

$01 / 01 / 90-12 / 31 / 90$

TO HELP CHARACTERIZE THE ORIGINS AND ESTIMATE THE AGES OF SOME HYDROGENIC DEPOSITS, DATA FROM STRONTIUM ISOTOPE ANALYSES OF CARBONATES ARE COMPARED. SAMPLE DATA FROM SOILS, VEINS, EOLIAN DUST, AND PALEOZOIC BASEMENT TAKEN SOUTH AND WE T OE YMOM EAST OF YM AND TO SAMP LE DATA FROR WATER, SR ISOTOPE RATIOS TERT TARY AQOIFER PRESENTED IN HISTOGRAMS.

ACQN/DEVI LOCATION : USGS, DENVER, CO.

*GS931108315215.033 FLUID INCLUSION TEMPERATURES FROM DRILI HOLES USW G-1 AND G-2, OCT. 92 - SEPT. 93.

$10 / 01 / 92-09 / 30 / 93$

NWM-USGS GCP-27, R0, DETERMINATION OF INITY FROM MINERAL-HOSTED FLUID INCLOSIONS.

ACQN/DEVI LOCATION : HARVARD UNIV., CAMBRIDGE, MA $\begin{array}{ll}\star G S 931108315215.034 & \text { CARBON 14 AGES FROM DRILI HOLES USW G-1. } \\ \text { G-2, GU-3, AND G-4, APRIL } 92 \text { - JAN. } 93 .\end{array}$

04/01/92-01/31/93 DATA WERE ACOUIRED BY DR. T. STAFFORD OF THE UNIVERSITY OF COLORADO. CARBONATE CARBON WAS EXTRACTED BY STANDARD 1 CC CARBON WRES AND THE $14 \mathrm{C}$ CONTENT WAS DETERMINED BY AMS AT LAWRENCE LIVERMORE NATIONAI IABORATORIES.

ACQN/DEVI LOCATION : LINL, LIVERMORE, CA

UNIV. OF COLORADO, BOULDER, CO 
DATA TRACKING NO.

TITLE/DESCRIPTION

ACQN/DEVL PERIOD EXTRACTION OF THE SILICATE OXYGEN

ACON/DEVL LOCATION : ASU, TEMPE, AZ

*GS931208315215.036 STABLE ISOTOPE COMPOSITION OF SOIL CO2, MARCH 93 - SEPT. 93.

ACQN/DEVL LOCATION : USGS, DENVER, CO

*GS931208315215.037 ISOTOPIC STUDIES OF YUCCA MOUNTAIN SOI FIUIDS AND CARBONATE PEDOGENESIS, BY T. MCCONNAUGHEY, K. WICKLAND, AND $\mathrm{J}$ WHELAN.

ACON/DEVL LOCATION : JS'SS, DENVER, CO
DATA WERE ACOOIRED BY DR. 1. KNAUTH OF ARIZONA STATE UNIV. DR. KNAUTH IS AN ARIZONE STEPWISE FLUORINATION OF OPALINE SILICA TO REMOVE EXTRANEOUS WATER PRIOR TO

A $P$

03/01/93-09/30/93 NWM-USGS GCP-33, RO, EXTRACTION OF SO CO2 FOR STABLE ISOTORE ARAI AND OXYGEN STABLE ISOTOPE ANALYSES.

$09 / 01 / 93-12 / 17 / 93$ Y MINERALS PRECIPITATED FROM

FRACTURES, AND FAOLTS, AND ORGANISMS ISOTOPIC COMPOSITIONS OF THE PARENT FLOIDS. TO INCREASE ACCURACY OF THIS PROCESS ISOTORIC COMPOSITIONS OE MODERN SOIL FLUIDS ARE COMPARED, WHERE POSSIBLE WITH MODERN CARBONATE PRECIPITATES
STODY OF ISOTOPIC COMPOSITIONS OF SEIDS PERCOLATING THROOGH SOILS, LIVING IN THOSE FLUIDS, TO INFER THE 
DATA TRACKING NO.

Activity - 8.3.1.8.5.1.2

*GS931008318512.009 40AR/39AR AGE OF THE IATHRCP WELIS VOICANIC CENTER, YUCCA MOUNTAIN, NEVADA VOLANIC CENER, DUANE CHAMPION, AND BOBERT J. FLECK

ACQN/DEVL LOCATION : USGS, DENVER, CO Activity - 8.3.1.9.2.1.1 *GS930908319211.001 NEW RADIOMETRIC AGES RELATED TO ALTERATION AND MINERALTAIN, NYE COUNTY, VICINITY OF YUCCA M. MCKEE AND JOEL R. NEVADA, BY

ACON/DEVL LOCATION : USGS, MENLO PARK, CA

Activity -8.3 .1 .9 .2 .1 .4$

*S931208319214.002 OII AND GAS EXPLORATION NEAR YOCCA MOUNTAIN, SOUTHERN NEVADA, BY J. GROW C. BARKER, AND A. HARRIS.

ACON/DEVL LOCATION : USGS, DENVER, CO
101/88-10/31/89 PALEOMAGNETIC AND 40AR/39AR ANALYSES WERE OSED TO PRODDCE ISOCHRON AND

USED TO PRODHRON PLOTS AND IDEOGRAMS

SHOWING INTEGRATED PROBABILITY

DISTRIBUTION OF $40 \mathrm{AR} / 39 \mathrm{AR}$.

01/01/86-12/31/90 AGE ANAIYSIS OF K-AR AND 40AR/39AR DATA
10/01/92-12/15/93 NON-YMP INFORMATION WAS REVIEWED INCLUDING D N P DRILLED IN 1991 IN THE AMARGOSA VALLEY, CONODONT ALTERATION INDICES, THERMAL MATURITY, AND ORGANIC GEOCHEMICAI ASSESSMENTS, TO COMPARE THE OIL AND GAS POTENTIAL OF YOCCA MOUNTAIN WITH THE PRODUCING AREA IN RAILROAD VALLEY. 
DATA TRACKING NO

Act1v1ty -8.3 .1 .14 .2 .2 .1$

*SNL02030193001.012 MECHANICAL PROPERTIES DATA (ULTRASONIC VELOCITIES, STATIC ELASTI - PROPERTIES, UELOCINED STRENGTH) FOR DRILLHOLE UE2S UNCDTF $896.5 \mathrm{FT}$.

ACQN/DEVL LOCATION : NER, INC., WHITE RIVER JUNCTION, VERMONT

*SNL02030193001.013 MECHANICAL PROPERTIES DATA (ULTRASONIC VELOCITIES, STATIC ELASTIC PROFERTIES, UNCONF INED STRENGTH, TENSILE STRENGTH, POROSITY) FOR DRILLHOLE UE 25 NRG-2B SAMPLES FROM DEPTH $2.7 \mathrm{FT}$. TO $87.6 \mathrm{FT}$.

$09 / 23 / 93-11 / 30 / 93$ COMPRESSION EXPERIMENTS AT 22 DEGREES C AND A STRAIN RATE OF 10E-5 S-1.". ASTM STM Dj967-92: "SPLITTING TENSILE STRENGIH OF INTACT ROCK CORE SPECIMENS.", ASTM STM D2845-90: "LABORATORY ITTERMINATION OF POLSE VELOCITIES AND OL.. RASONIC ELASTIC CONSTANTS OE ROCK.", ASTM STM D854-92 "TEST METHOD FOR SPECIFIC GRAVITY OF SOILS."

ACON/DEVI LOCATION : NER, INC., WHITE RIVER JUNCTION, VERMONT 


\section{Activity -8.3 .1 .14 .2 .2 .2$}

* SNL02030193001.001 MECHANICAL PROPERTIES [ATA (UITRASONIC VELOCITIES, STATIC ELASTIC PROEERTIES, UNCONF INED STRENGTH) FOR DRILLHOLE USW NRG-6 SAMPLES FROM DEPTH 22.2 FT. TO 328.7 FT.

ACON/DEVL LOCATION : NER INC., WHITE RIVER JUNCTION, VERMONT

* * SNL02030193001.002 MECHANICAL PROPERTIES DATA (ULTRASONIC MECHANICAL PROPERT ELASTIC PROPERTIES VELOCITIES, STATICH TRIAXIAL STRENGTH, UNCONF INED STRENGTH, TRIAXIAL GRAIN TENSILE STRENGTH, \& AVERAGE GRA 6 SAMPLES DENSITY) FOR DRI T'T TO 427.0 FT.

$04 / 01 / 93-06 / 23 / 93$

ACON/DEVI LOCATION : NER INC., WHITE RIVER JUNCTION, VERMONT

* SNI02030193001.003 MECHANICAL PROPERTIES DATA (ULTRASONIC VELOCITIES, STATIC ELASTIC PROPERTIES, UNCONFINED STRENGTH, TENSILE STRENGTH, AVERAGE GRAIN DENSITY) FOR DRILIHOLE UE-25NRG\#2 SAMPLES FROM DEPTH $170.4 \mathrm{FT}$ TO $200.0 \mathrm{FT}$.

$04 / 01 / 93-07 / 07 / 93$

STANDARD LABORATORY ROCK MECHANICS PROCEDURES AS PER TP-219: 22 DEGREES C COMPRESSION EXPERIMENTS AT 22 DEGREES C AND A STRAIN RATE OF 1OE-5 S-1. "ASTM STM D3967-92: "SPLITTING TENSILE STRE STM INTACT ROCK CORE SPECIMENS", ASTM STM OF D2845-90: "LABORATORY DETERMINATION OF CONSTANTS OF ROCK".

STANDARD LABORATORY ROCK MECHANICS

PROCEDURES AS PER TP-219 "UNCONFINED AND A STRAIN RATE OF 1OE-5 S-1.", ASTM STM 3967-92 "SPIITTING TENSILE STRENGTH OF INTACT ROCK CORE SPECIMENS", ASTM STM D2845-90 "LABORATORY DETERASONIC ELASTIC CONSTANTS OE ROCK".

ACON/DEVI IOCATION : NER, INC., WHITE RIVER JUNCTION, VERMONT 
DATA TRACKING NO.

TITLE/DESCRIPTION

* *SNL02030193001.005 MECHANICAL PROPERTIES DATA (OLTRASONIC VELOCITIES, STATIC ELASTIC PROPERTIES, UNCONF INED STRENGTH, TENSILE STLEHOLE AVERAGE GRA SAMPLES FROM DEFTH 15.4 FT. TO 297.1 FT.

ACON/DEVI PERIOD

$06 / 18 / 93-09 / 13 / 93$ COMPRSSION EXPERIMENTS AT 22 DEGREES C COM 10E-5 s-1.", ASTM AND A STRA-92: "SPLITTING TENSILE STRENGTH STM D 3967-92: "SRE SPECIMENS", ASTM STM OF INTACT "ARORATORY DETERMINATION OF D2845-90: PULSE VELS OF ROCK."

ACQN/DEVL LOCATION : NER, INC., WHITE RIVER JUNCTION, VERMONT

*SNL02030193001.006 MECHANICAL PROPERTIES DATA (ULTRASONIC VEIOCITIES, STATIC ELASTIC PROPERTIES, INONFINED STRENGTH, TENSILE STRENGTH, AVCRAGE GRAIN DENSITY) FOR DRILL HOLE AVERAGE 2 SAMPLES FROIA DEPTH $90.0 \mathrm{FT}$. TO 254.5 FT.

$08 / 13 / 93-10 / 08 / 93$

(1)

TANDARD IABORATORY ROCK MECHANICS

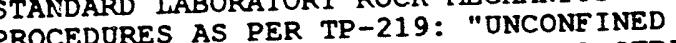
EXPERIMENTS AT 22 DEGREES C AND A STRAI RATE OF 1OE-5 $s-1 . "$, ASTM STM D 3967-92: "SPLITTING TENSILE STRENGTH OF INTACT CORE SPECIMENS." ASTM STM D2845-90: "LABORATORY DETERMINATION OF PULSE CONSTANTS OF ROCK."

ACON/DEVL LOCATION : NER, IN ., WHITE RIVER JUNCTION, VERMONT

MCQN/DEVL LOCATION: NER, INC.' WHLIE MECHANICAL PROPERTIES DATA TOLTRASONIC VELOCITIES, STATIC ELASTIC PRORERTIES TRIAXIAL STRENGTH, A AVERAGE GRAIN DENSITY) FOR DRILI HOLE UE-25NRG $\$ 3$ SAMPLES FROM DEPTH 263.3 FT. TO 265.7 FT. 06/18/93-09/20/93 ASTM STM D2845-90: "LABORATORY DETERMINATION OF POLSENTANTS OF ROCK.", OLTRASONIC ELASTIC CONS FOR DETERMINING ISRM "SUGGESTED METH MATERIALS IN TRIAXIAL THE STRENGTH OF ROCK VERSION", 1983

ACQN/DEVL LOCATION : NER, INC., WHITE RIVER JUNCTION, VERMONT 
DATA TRACKING NO.

TITLE/DESCRIPTION

ACQN/DEVI PERIOD
*SNL02030193001.008 MECHANICAL PROPERTIES D.3TA. (UITRASONIC VELOCITIES, STATIC ELASTIC PROPERTIES, VELOCITIES, STATH ELAVEAGE GRAIN TRIAXIAL STRENGTH, 416.0 ET.

ACON/DEVL LOCATION : NER, INC., WHITE RIVER JONCTION, VERMONT

* SNL02030193001.009 MECHANICAI PROPERTIES DATA ITENSILE STRENGTH, AVERAGE GRAIN DENSITY, \& POROSITY) FOR DRILLHOLE UE 25 NRG SAMPLES FROM DEPTH 781.0 FT. TO 991.9 FT.

ACON/DEVL LOCATION : NER, INC., WHITE RIVER JUNCTION, VERMONT

*SNL02030193001.010 MECHANICAL PROPERTIES DATA (AVERAGE

$09 / 23 / 93-11 / 02 / 93$ MECHANICAL PROPERTIES DATA (AVERAGE NRG-2B GRAIN DENSITY) FOR DRILAT. TO $87.6 \mathrm{FT}$ ACON/DEVL LOCATION : NER, IHC., WHITE RIVER JUNCTION, VERMONT

*SNL02030193001.011 MECHANICAL PROPERTIES DATA (POROSITY)

$08 / 13 / 93-11 / 02 / 93$ FOR DRILLHOLE OE25 NRG-2A SAMP
DEPTH $135.3 \mathrm{FT}$. TO $166.5 \mathrm{ET}$.

ACON/DEVI LOCATION : NER, INC., WHITE RIVER JUNCTION, VERMONT
STM STM D2845-90: "LABORATORY

DETERMINATION OF POLSE VELOCITIES AND

ULTRASONIC ELASTIC CONSTANTS OF ROCK."

ISRM "SUGGESTE METK MATERIALS IN TRIAXIAI

THE STRENGTH OF ROCK MATERIAL", 1983
$08 / 13 / 93-11 / 04 / 93$

ASTM STM D3967-92: "SPLITTING TENSILE STRENGTH OF INTACT ROCK CORE SPECIMENS." AND ASTM STM D854-92: "TEST METHOD FOR SPECIFIC GRAVIT: OF SOILS."
ASTM STM D854-92: "TEST METHOD FOR SPECIFIC GRAVITY OF SOILS."

ASTM STM D854-92: "TEST METHOD FOR 
DATA TRACKING NO.

TITLE/DESCRIPTION

ACON/DEVL PERIOD

*SNL02030193001.012 MECHANICAL PROPERTIES DATA (ULTRASONIC VELOCITIES, STATIC ELASTIC PROPERTIES, \& NRG-5 SAMPIES FROM DEPTH 847.2 FT. TO 896.5 FT.

$08 / 13 / 93-11 / 30 / 93$ STANDARD LABORATORY ROCK MECHANICS PROCEDURES AS PER TP-219: "UNCONFINED COMPRESSION EXPERIMENTS AT 22 DEGRES AND A STRAIN RATE OF 1OE D2845-90: "LABORATORY DETERMINATION OF OF ROCK."

ACQN/DEVL LOCATION : NER, INC., WHITE RIVER JUNCTION, VERMONT

*SNL02030193001.013 MECHANICAL PROPERTIES DATA (ULTRASONIC VELOCITIES, STATIC ELASTIC FROPERTIES, UNCONFINED STRENGTH, TENSILE STRENGTH, POROSITY) FOR DRILLHOLE UE25 NRG-2B SAMPLES FROM DERTH $2.7 \mathrm{FT}$. TO $87.6 \mathrm{FT}$

$09 / 23 / 93-11 / 30 / 93$

STANDARD LABORATORY ROCK MECHANICS PROCEDURES AS PER TP-219: "UNCONFINED COMPRESSION EXPERIMENTS AI 22 DEGREES C AND A STRAIN RATE OF 10E-5 $s-1 . "$, ASTM STM D3967-92: "SPLITTING TENSILE STRENGTH OF DCT ROCK CORE SPECIMENS.", ASTM STM 12845-ग0: "LABORATORY DETERMINATION OF PULSE VELOCITIES AND OLTRASONIC ELASTIC CONSTANTS OF ROCK." \& ASTM STM D854-92: TTST METHOD FOR SPECIFIC GRAVITY OF SOILS."

ACON/DEVI LOCATION : NER, INC., WHITE RIVER JUNCTION, VERMONT 
DATA TRACKING NO. TITLE/DESCRIPTION

ACQN/DEVL PERIOD

Act1vity - 8.3.1.14.2.3

*SNE29041993002.002 YUCCA MOUNTAIN SITE CHARACTERIZATION PROJECT GEOLOGY AND ROCK STRUCTURE LOC FOR DRILLHOLE RF \#8.

06/01/93-06/30/93 SCIENTIFIC NCTEBOOK FOR GEOTECHNICAL

A N P COGGING OF CORE BY EXAMINATION OF CORE IND VIDEO RECORDS FROM NRG HOLES AND INSTROCTIONS FOR ESTABLISHING QA RECORDS BASED UPON TSMSS ROCK STROCTURE LOGS.

ACON/DEVL LOCATION : YMP SAMPLE MANAGEMENT FACILITY *SNF29041993002.003 YUCCA MOUNTAIN SITE CHARACTERIZATION

$05 / 01 / 93-05 / 30 / 93$ PROJECT GEOLOGY 25 NRG-1.

TOTECHNICAL CORE LOGGING OF UE25 NRG-1. SCIENTIF IC NORE BY EXAMINATION OF CORE AND VIDEO RECORDS FROM NRG HOLES AND INSTRUTTONS FOR ESTABIISHING OA RECORDS INITROCTION TIMS ROCK STRUCTURAL LOGS.

ACQN/DEVI LOCATION : YMP SAMPLE MANAGEMENT FACILITY

* SNF 29041993002.004 YUCCA MOUNTAIN SITE CHARACTERIZATION

08/01/93-08/31/93 GEOTECHNICAL CORE LCGGING OF OE25 NRG-2A. YOCCA MOUNAT SI AND ROCK STRUCTURE LOG SCIENTIFIC NOTEBOOK FOR GEOTECHNICAL CORE LOGGING BY EXAMINATION OF CORE AND RECORDS FROM NRG HOLES AND INSTRUCTIONS RECORDS BASED UPON T\&MSS ROCK STRUCTURAI LOGS.

ACQN/DEVL LOCATION : YMP SAMPLE MANAGEMENT FACILITY

* SNF29041993002.005 YUCCA MOUNTAIN SITE CHARACTERIZATION PROJECT GEOLOGY AND ROCK STRUCTURE LOG

$06 / 01 / 93-06 / 30 / 93$ PROJECT GEOLOGY AN 5 NRG-3.

ACON/DEVL LOCATION : YMP SAMPLE MANAGEMENT FACILITY

GEOTECHNICAL CORE LOGGING OF UE25 NRG-3. GEOTECHNICAL CORE LOGGING OF CORE BY EXAMINATION OF CORE AND VIDEO RECORDS FROM NRG HOLES AND IDSRUCTIONS FOR ESTABLISHING QA RECORDS BASED UPON T\&MSS ROCK STRUCTORAL LOGS 
DATA TRACKING NO.

TITLE/DESCRIPTION

ACON/DEVI PERIOD

4UCCA MOUNTAIN SITE CHARACTERIZATION PROJECT GEOLOGY AND ROCK STRUCTURE LOG FOR DRILLHOLE USW NRG- 6 .

SCIENTIFIC NOTEBOOK FOR GEOTECHNICAL

SCIETHG OE CORE BY EXAMINATION OF CORE AND

VIDEO RECORDS FROM NRG HOLES AND

INETRDTIONS FOR ESTABIISHING OA RECORDS

BNSTR UPON TEMSS ROCK STROCTURAL LOGS.

ACON/DEVL LOCATION : YMP SAMPLE MANAGEMENT FACILITY

* SNE29041993002.007 YUCCA MOUNTAIN SITE CHARACTERIZATION YROCA MOUNATIN AND ROCK STRUCTURE LOG PROR DRILLHOLE UE25 NRG $-\bar{j}$.
08/01/93-08/30/93 GEOTECHNICAI CORE IOGGING OF UE25 NRG-5. GEOTECHNICAL CORE LOGGING OF OE25 NRG PREPARED IN ACCORDANCE WITH SCIENT IF IC NOTEBOOK FOR GEOTECHNE AND VIDEO RECORDS BY EXAMINATION OF CORE ANDTIONS FOR

FROM NRG HOLES AND INSTRUCTIONS FOR ESTABLISHING QA RECOR
ROCK STRUCTURE LOGS

ACON/DEVL LOCATION : YMP SAMPLE MANAGEMENT FACILITY AND JFT AGAPITO

*SNF 29041993002.008 YUCCA MOUNTAIN SITE CHARACTERIZATION PROJECT GEOLOGY AND ROCK STRUCTURE LOG FOR DRILLHOLE UE25 NRG-4.
10/01/93-10/29/93 GEOTECHNICAL CORE LOGGING OF UE25 NRG-4 PREPARED IN ACCORDANCE WITH SCIENTIFIC NOTEBOOK FOR GEOTECHNICAL LOGGING OF CORE BY EXAMINATION OF CORE AND VIDEO RECORDS BROM NRG HOIES AND INSTRDCTIONS FOR ESTABIISHINA OA RECORDS BASED OPON T\&MSS ESTABLISHING QA RECORI

ACON/DEVL LOCATION : YMP SAMPLE MANAGEMENT FACILITY AND JFT AGAPITO 
DATA TRACKING NO.

TITLE/DESCRIPTION

ACQN/DEVL PERIOD

ACQN/DEVL METHOD

$11 / 01 / 93-11 / 30 / 93$

NRG-2A， NRG-3， NRG-4, NRG-5\& NRG-6.

PREPARED IN ACCORDANCE WITH SCIENTIFIC

NOTEBOOK FOR GEOTECHNICAL LOGGING OF CORE

OY EXAMINATION OF CORE AND VIDEO RECORDS

FROM NRG HOLES AND INSTRUCTIONS FOR

FRTABISHING OA RECORDS BASED UPON TEMSS ROCR STRUCTURE LOGS.

ACQN/DEVL LOCATION : J. F. T. AGAPITO

Activity - 8.3.1.15.1.1.3

AMT 01 THE 5059301.001 THAL CONDOCTIVITY DATA FROM USW NRG-6 CONDUCTIVITY DATA $28.8 \mathrm{FT}$. TO DRILLHOLE

05/01/93-11/01/93 GUARDED-HEAT-FLOW-METER METHOD

ACON/DEVI LOCATION : HOLOMETRIX, BEDFORD, MASS.

Activity - 8.3.1.15.1.2.1

SNI01805059301.002 THERMAL EXPANSION DATA EROM USW NRG-6

05/21/93-11/11/93 SINGLE PUSH-ROD DILATOMETER.

A Y P $416.0 \mathrm{FT}$.

ACON/DEVL LOCATION : HOJOMETRIX, BEDFORD, MASS. 
UNIAXIAL AND TRIAXIAL COMPRESSION TEST AT CONSTANT STRAIN-RATE WERE RUN ON SAMPLES

*SNSAND80145300.000 SAND80-1453: "ROCK MECHANICS PROPERTIE OF VOLCANIC TUFFS FROM THE NEVADA TEST SITE." NNA.870406.0497

ACON/DEVL LOCATION : SN

Activity - 8.3.1.15.1.4.1

$\star \star$ SNSAND 80145300.000

SAND80-1453: "ROCK MECHANICS PROPERTIES SAND 1 - TUFFS FROM THE NEVADA TEST SITE." NNA.870406.0497
$11 / 01 / 78-07 / 01 / 80$

ONIAXIAL AND TRIAXIAL COMPRESSION TEST AT CONSTANT STRAIN-RATE WERE RUN ON SAMPLES FROM HOLE UE25A\#1 AND G-TUNNEL, BOTH LOCATED ON THE NEVA SITE. TESTING IS ACCOMPLISHED IN A $1.8 \mathrm{GN}$ OLTRA-STIFF, ELECTRO-HYDRAOLIC

SERVO-CONTROLLED COMPRESSION TESTING MACHINE. RAM DISPLACEMENT IS USED AS THE PROGRAMMED FEEDBACK VARIABLE. (FOR MORE DETAIL SEE SAND80-1453) 
Activity - 8.3.1.15.1.8.1

* SNF28021693001.001 SITR93-7001. ESTIMATION OF ROCK MASS SLTR93-7001, ESTIMATION OE ROCK MAS QUALITY OF THE NORTH RAIP ETARTER UNANG TUNNEL: (ROCK MAS" SYSTEM).

04/15/93-07/16/93 BREDIMINARY ROCK MASS OUAIITY WAS ASSESSED A $Y C$ PREIIMINARY ROCK MASS QUALI TUNNEL USING BASED ON EXAMINATION OF THE TUNNEL USIN MORE "QETAILED DESCRIPTION)

ACQN/DEVI LOCATION : IOP HEADING OF THE NORTH RAMP STARTER TUNNEL

Activity -8.3 .1 .16 .1 .1 .1$

* GS931183116111.002 NEVADA TEST SITE FLOOD INUNDATION STUDY - PART OE U.S. GEOLOGICAL SURVEY FLOOD POTENTIAI AND DEBRIS HAZAR.D STUDY, YO MOUNTAIN SITE, BY JAMES O. BLANTON III.

ACQN/DEVI LOCATION : USBR, DENVER, CO

*GS931183116111.003 NEVADA TEST SITE PROBABZE MAXIMUM FLOOD STUDY - PART OF U.S. GEOLOGICAL SURVEY FTUDY POTENTIAL AND DEBRIS HAZARD STUDY, YUCCA MOUNTAIN SITE, BY KENNETE $i$. BULLARD.

ACQN/DEVL LOCATION : USBR, DENVER, CO
06/07/91-05/24/92 DEVELOPED USING PROBABLE MAXIMOM FLOOD TECHNIQUE AND METHOD DEFINED IN YMP-OSBR HP-03,RO SPECIAL FROCESS FOR DETERMINING WATER SURFACE PROFILES AND ELOOD INONDATED SURFACE AREAS.

$06 / 07 / 91-05 / 24 / 92$

DEVELOPED OSING PROBABIE MAXIMUM FLOOD TECHNIOOE WHICH COMPIIES WITH ANSI TECHNIQUE WHICH COMPINING DESIGN BASIS STANDARD FOR DETER REACTOR SITES. 
DATA TRACKING NO.

TITLE/DESCRIPTION

ACQN/DEVL PERIOD ACQN/DEVL METHOD

Activity - 8.3.1.17.4.1.2

*GS931083117412.002 SGB LOCAL EARTHQUAKE ARCHIVE TAPES CONTAINING DATA FROM JUNE 1993 THROUGH CONTAINING DATA FROMES L1247 THROUGH

$06 / 01 / 93-09 / 30 / 93$ L1256.

ACON/DEVL LOCATION : SOUTHERN GREAT BASIN SEISMIC NETWORK

*GS931083117412.003 PRELIMINARY SEISMICITY AND FOCAL MECHANISMS FOR THE SOUTHERN GREAT BASIN OF NEVADA AND CALIFORNIA: JANUARY 1992 THROUGH SEPTEMBER 1992, BY S.C. HARMSEN

ACQN/DEVI LOCATION : USGS BELH, GOLDEN, CO

Activity - 8.3.1.17.4.2.1

*GS930883117421.002 MAPPING AND CHARACTERIZING THE SURFICIAL PROPERTIES OF THE OUATERNARY DEPOSITS OF MIDWAY VALIEY USING AIRPHOTOS AND EIELD MIDWAY VALIEY USING AIRPACE SOII DATA RECO RECORDED EROM SOII PITS MWV-P1 WERE RECORDED 10 MWV-P 12 THROUGH THROUGH MWV MWV-P17, MWV-P19 THROUGH MW THESE MWV-P28 THROOCH MWV-P 31 CN THESE
$05 / 01 / 93-10 / 13 / 93$ REDUCTION OF SEISMOGRAMS OBTAINED FROM THE D $Y$ P SGBSN USING COMPUTER MODEL HYPOTI.

SP-11,R3, OPERATION AND CALIBRATION OF REMOTE TELEMETERED SEISMIC ARRAY

02/01/90-09/13/93 PROCEDDRE GP-17,R1, DESCRIBING AND PROCEDURE GP 17 IN THE FIELD, WAS FOLLOWED SAMPIING SOILS IN THE FIELD, WAS FOLLTS. DESCRIBING AND SAMPIING SOIL MAPPING, WAS PROCEDURE GP-O1, R2, GEOLOGIC MAPEING, WAS IN MIDWAY VALLEY. 


\section{Activity - 8.3.1.17.4.3.2}

*S930783117432.012 COMPILATION OF KNOWN AND SCSPECTED OUATERNARY FAULTS WITHIN $100 \mathrm{KM}$ OF YUCCA

$10 / 01 / 92-06 / 01 / 93$ COMPILATION OF POBLISHED LITERATURE AND READILY AVAILABLE DATA. MOONTAIN, BY I.A. PIETY.

ACQN/DEVI LOCATION : USBR, DENVER, COLORADO

$06 / 17 / 93-06 / 19 / 93$

GP-52, R0, TOPOGRAPHIC PROFILING OF GEOMORPHIC FEATURES -- FIELD MEASUREMENT

*GS931083117432.001 ACON/DEVL LOCATION: $3648^{\prime} 00^{\prime \prime N} 11645^{\prime} 00^{\prime \prime}$ : $36 \quad 52^{\prime} 30^{\prime \prime} \mathrm{N} 11642^{\prime} 00^{\prime \prime} \mathrm{W}$

Activity - 8.3.1.17.4.5.2

*GS931283117452.005 GEOLOGIC MAPPING IN CRATER FLAT, IN AND CRATER ELAT, IN EAST OF BEATTY MOUNTAIN, 2) BEATTY MOUNTAIN, 3) CRATER FLAT, 4) BIG DUNE ACQN/DEVL LOCATION : $3652^{\prime} 30^{\prime \prime} \mathrm{N} 11637^{\prime} 30$ "W; $3700^{\prime} 00^{\prime \prime N} 11630^{\prime} 00^{\prime \prime} \mathrm{K}$

\section{3/14/93-05/15/93 TECHNICAI MEPPING.}

*GS931283117452.006 GEOLOGIC MAP OF THE EAST OF BEATTY MOUNTAIN 7.5 MINUTE QUADRANGLE, NY COUNTY, NEVADA, BY C.J. FRIDRICH, R. ORKILD, M. MORRAY, J.R. PRICE, R.LAR, CHRISTIANSEN, P.W. LIPMAN, N.JT.

W.D. QUINLIVAN 
SITE CHARACTERIZATION PLAN BASELINE

DATA TRACKING NO.

TITLE/DESCRIPTION

ACQN/DEVL PERIOD

ACQN / DEVL METHOD

03/29/91-07/22/93 THE DATA WERE COLLECTED ONDER NWM-USGS GP-01, R1 AND R2, GEOLOGIC MAPPING.

GEOLOGIC MAPPING IND FIELD OBSERVATIONS PERTAINING TO OUATERNARY FAULTING

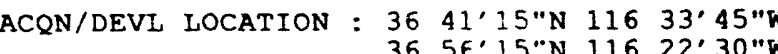

«GS931183117461.004 PRELIMINARY QUATERNARY FAULT MAP OF THE YUCCA MOUNTAIN REGION, BY F. SIMONDS, J WHITNEY, K. FOX, A. RAMELLI, J. YOUNT, M. CARR, C. MENGES, R. DICKERSON AND R. SCOTT.

ACQN/DEVL LOCATION : USGS, DENVER, CO Activity - 8.3.1.17.4.6.2

*GS931283117462.006 PRELIMINARY TRENCH LOG, AND ACCOMPANYING DESCRIPTIONS AND DATA SHEETS FOR LITHOLOGIC UNITS, SOILS. AND DEFORMATION, FOR TRENCFES SCR-TI AND SCR-T3 (PARTS OF BOTH NORTH AND SOOTH WALIS IN EACH TRENCH). JOGS AND DATA PREPARED BY C. MENGES, J. OSWALD AND J. COE. EACH LOG INCLUDES CEILING MAPPED PHOTOGRAMETRICALLY AND MANUALIY (WITH CONVENTIONAL METHOD).

ACQN/DEVI LOCATION : N718620(N) E556680(N)
07/01/93-08/31/93 MAP WAS PLOTTED FROM THE INFORMATION OBTAINED THRODGH FIELD OBSERVATIONS.

05/01/93-10/31/93 TECHNICAL PROCEDURE NWM-USGS GP-07,R1, CONVENTIONAL GEOLOGIC MAPPING OF TRENCH WALLS, AND TECHNICAL PROCEDURES NWM-USGS GP-39, RO, GEOPHOTOGRAMMETRIC MAPPING O GP-40, R0, GEOPHOTOGRAMMETRIC MAPPING OF TRENCH WALIS - LABORATORY METHODS. TRENCH WALLS: FIELDWORK; AND NWM-USGS 
DATA TRACKING NO.

*GS931283117462.007 U-TH ISOTOPIC DATA FOR J-SERIES DISEQUILIBRIUM DATING OF PEDOGENIC CARBONATE ASSOCIATED WITH QUATERNARY FAULTING ON THE EAST SI E OF YUCCA MOUNTAIN. DATA INCLUDE SAME LE RND SPIH WEIGHTS, AND CUMULATIVE ALPHA [ECAY COUNTS EOR $238 U$, S CALCULATED U AND TH CONCENTRATIONS, ACTIVITY RATIOS AND CORRELATION COEFFICIENTS.

ACON/DEVL LOCATION : OSGS U-SERIES LABS, DENVER, CO

AGE CALCULATED FROM ACQ:IRED U-TH ISOTOPIC DATA.

ACQN/DEVL LOCATION : US IS U-SERIES LABS, DENVER, CO
$11 / 01 / 93-12 / 15 / 93$

230TH/2380 CALCULATIONS DETERMINED BY MIXING IINE REGRESSION OSING MAXIMUM LIKELIHOOD ESTIMATION ALGORITHMS (LODN AND TITTERINGTON, MAXIMUM LIRELIROOD FOR ESTIMATION OF U-TH ERRORS, IN REVIE ACTA)

$06 / 06 / 89-06 / 21 / 91$

ANAIYTICAL AND INTERPRETIVE METHODS BASED ON THE AUTHORS' COMBINED EDUCATION AND WORR EXPERIENCES WERE USED TO DEVELOP THIS ARTICLE SOURCE METHODS FOR DEEP CRTSTAL SEISMIC REFIECTION PROFIIING IN THE BASIN AND RANGE PROVZNCE, BY T.M. BROCHER AND P.E. HART. ACQN/DEVI LOCATION : USGS, MENLO PARK, CA Activity -8.3 .1 .17
$*$ GS 920283117471.004 
SITE CHARACTERIZATION FIAN BASELINE

DATA TRACKING NO

TITLE/DESCRIETION

Activity $-8.3 \cdot 1 \cdot 17 \cdot 4 \cdot 10.2$

*GS931031174102.001 STRAIN ACCUMULATION NEAR YUCCA MOUNTAIN, NEVADA, 1983 - 1993, BY J.C. SAVAGE, M. LISOWSKI, W.K. GROSS, N.E. KING, AND J.L. SVARC.

ACQN/DEVL LOCATION : USGS, MENLO PARK, CA

*GS931031174102.002 SURVEY OF DEFoRMATION OF 50-KM-APERTURE TRILATERATION NETWORK USING A GEODOLITE, TRILATERATION NETWORK USING A GEODOLITE,
CENTERED ON YUCCA MDUNTAIN, 1983-1984.

ACQN/DEVL LOCATION : USGS, MENLO PARK, CA

SURVEY OF DEFORMATION OF SO-KM-APERTURE TRILATERATION NETWORK USING GPS AND A GEODOLITE, CENTERED ON YUCCA MOUNTAIN 1993

ACQN/DEVL LOCATION : USGS, MENLO PARK, CA
$06 / 01 / 83-06 / 30 / 83$ $06 / 01 / 84-07 / 31 / 84$

07/01/93-07/30/93 DATA WERE DEVELOPED ACCORDING TO THE AUTHORS' EDUCATIONAL AND TECHNICAL EXPERIENCE.

THE PROCEDURES USED AND THE ACCURACY ATTAINED FOR THESE SURVEYS ARE DESCRIBED IN SAVAGE AND PRESCOTT (1973), PRECISION OF GEODOLITE DISTANCE MEASUREMENTS FOR DETERMINING FAULT MOVEMENTS, J. GEOPHYS. RES., 78, 6001-6008.

04/01/93-05/30/93 TECHNTCAL PROCEDURE NWM-USGS GP-43,R0, TECHNTCAL PROCEDURE NWM-USGS GP-A GEODETIC TRILATERATION AND GLOBAL 
DATA TRACKING NO. TITLE/DESCRIPTION

ACQN/DEVL PERIOD

ACQN/DEVL METHOD
Activity - 8.3.2.4.1.1

*SNSAND 92185300.000 SAND 92-1853: "EFFECT OF BOUNDARY CONDITIONS ON THE STRENGTH AND DEFORMAB FRACTURES IN WELDED TUFF: DATA REPORT"

ACON/DEVL LOCATION : UNIVERSITY OF COLORADO AT BOULDER
O6/19/92-08/01/93 EP-44. EP-44, "NORMAL COMPRESSION AND SHEAR TEST ON ROCK JOINTS." FOOR SERIES OF CYCLIC DIRECT-SHEAR EXPERIMENTS WERE CONDOC

SEVERAL REPLICAS OF TMREE NATURAL OF WELDED FRACTURES AND A TENSILE FRACTURE OF WELDED TUFF FROM YUCCA MOUNTAIN. OBJECTIVE WAS TO EXAMINE THE EFFECT OF CYCLIC LOADING

JOINT SHEAR BEHAVIOR UNDER DIFFERENT

BOUNDARY CONDITIONS. SHEAR TESTS WERE PERFORMED UNDER EITHER DIFFERENT LEVE 0.6 COND 25,6 KIPS OR CONSTANT NORMAL STIFFNES AND 25.6 KETWEEN 14.8 AND $187.5 \mathrm{KIPS/IN}$

(FOR MORE DETAIL SEE SAND92-1853) 
DATA TRACKING NO.

TITLE/DESCRIPTION

The 30050393001.002

*SNF 30050393001.00

SNL NORTH RAMP STARTER TUNNEL ROCK-MASS MONITORING DATA: PLOTS OF DRIFT CONVERGENCE AND CONVERGENCE RATE FOR ESE CONOEGENCE AND COND PIOTS OF ROCK BOLT LOAD CELLS.

ACQN/DEVL LOCATION : NEVADA TEST SITE-NORTH PORTAL/ESF STARTER TUNNEL

† SNI 12011393001.003 NICKEL SORPTION ONTO DIFFERENT SUBSTRATE SUBSTRATES ISED WERE WEDRON S10 SAND, SYNTHETIC GOETHITE, AND ACID-WASHED MIN-U-SIL QUARTZ

ACON/DEVL LOCATION : SNL, ALBUQUERQUE, NM *SNL12072193001.001 NOTEBOOK MIT-SAND-AC-6869-1 IN SUPPORT URANIUM DISTRIBUTION COEFFICIENTS IN UNSATURATED MEDIA".

ACON/DEVL LOCATION : MIT, CAMBRIDGE, MASS.
ACON/DEVL PERIOD

ACON/DEVL METHOD

A $\mathbf{N}$ C

06/01/93-09/30/93 MAKE DISPLACEMENT MEASUREMENTS USING A TAPE EXTENSOMETER; CHECK ROCK BOLT LOAD TAPE EXTENSOMETER, CS WITH A VOLTMETER. 03/26/93-09/20/93 DATA OBTAINED BY BATCH SORPTION METHODS; REDUCED USING EXCEL SPREAD SHEET.

$12 / 01 / 92-10 / 01 / 93$ DNSATURATED SORPTION MEASUREMENTS USING TURBULA MIXER, ANALYSIS BY ICP. 
DATA TRACKING NO.

TITLE/DESCRIPTION

ACQN/DEVL PERIOD

ACQN/DEVL METHOD

01/01/93-09/30/93 MONITORING OF YUCCA MOUNTAIN SITE
CHARACTERIZATION PROJECT CHARACTE

YUCCA MOUNTAIN SITE CHARACTERIZATION PROJECT SOCIOECONOMIC MONITORING PROGRAM 1993 EMPLOYEE SURVEY DATA REPORT, STATE \& COUNTY DATA, SEPTEMBER 1993

ACQN/DEVL LOCATION : TEMSS

^TM00121361T1EB.001 YUCCA MOUNTAIN SITE CHARACTERIZATION PROJECT SOCIOECONOMIC MONITORING PROGRAM PROJECT SOCIOECONOMIC MONITORING PROGRAM

QUARTERLY EMPLOYMENT DATA REPC
1993 THROUGH SEPTEMBER 1993

ACQN/DEVL LOCATION : T\&MSS $\begin{array}{ll}01 / 01 / 93-09 / 30 / 93 & \text { MONITORING OF YUCCA MOUNTAIN SITE } \\ \text { CHARACTERIZATION PROJECT CHARACTERISTICS }\end{array}$

AS DESCRIBED IN REVISION O OF THE

SOCIOECONOMIC PLAN

07/01/93-09/30/93 MONITORING OF YOCCA MOUNTAIN SITE CHARACTERIZATION PROJECT CHARACTERISTICS CHARACTERIZATION PRSTIBED IN REVISION $O$ OF THE SOCTOECONOMIC PLAN
TDEVL IOCATTON : T\&MSS 


\section{APPENDIX A}

SITE CHARACTERIZATION PROGRAM BASELINE ACTIVITY NOMBERS AND NAMES ACTIVITY NO. ACTIVITY NAME

8.3.1.2.1.1.1 Precipitation and meteorological monitoring

8.3.1.2.1.2.1 Surface-water runoff monitoring

8.3.1.2.1.2.2 Transport of debris by severe runoff

8.3.1.2.1.3.1 Assessment of the regional hydrogeologic data needs in the saturated zones

8.3.1.2.1.3.2 Regional potentiometric-level distribution and hydrogeologic framework studies

8.3.1.2.1.3.3 Fortymile wash recharge study

8.3.1.2.1.3.4 Evapotranspiration studies

8.3.1.2.1.4.1 Conceptualization of regional hydrologic flow models

8.3.1.2.1.4.2 Subregional two-dimensional area hydrologic modeling

8.3.1.2.2.1.1 Characterization of hydrological properties of surficial materials

8.3.1.2.2.1.2 Evaluation of natural infiltration

8.3.1.2.2.2.1 Chloride and chlorine-36 measurements of percolation at Yucca Mountain

8.3.1.2.2.3.1 Matrix hydrologic properties testing

8.3.1.2.2.3.2 Site vertical borehole studies

8.3.1.2.2.4.2 Percolation tests in the Exploratory studies Facility

8.3.1.2.2.4.8 Hydrochemistry tests in the Exploratory Studies Facility

8.3.1.2.2.4.9 Multipurpose-borehole testing

8.3.1.2.2.6.1 Gaseous-phase circulation study 
8.3.1.2.2.7.1 Gaseous - phase chemical investigations

8.3.1.2.2.7.2 Aqueous-phase chemical investigations

8.3.1.2.2.8.1 Development of conceptual and numerical models of fluid flow in unsaturated, fractured rock

8.3.1.2.2.9.1 Conceptualization of the unsaturated-zone hydrogeologic system

8.3.1.2.2.9.3 Simulation of the natural hydrogeologic system

8.3.1.2.3.1.2 Site potentiometric-level evaluation

8.3.1.2.3.1.3 Analysis of single-and multiple-well hydraulic-stress tests

8.3.1.2.3.1.4 Multiple-well interference testing

8.3.1.2.3.1.6 Well testing with conservative tracers throughout the site

8.3.1.2.3.1.7 Testing of the C-hole sites with conservative tracers

8.3.1.2.3.2.1 Assessment of saturated-zone hydrochemical data availability and needs

8.3.1.2.3.2.2 Hydrochemical characterization of water in the upper part of the saturated zone

8.3.1.2.3.2.3 Regional hydrochemical tests and analyses

8.3.1.2.3.3.1 Conceptualization of saturated-zone flow models within the boundaries of the accessible environment

8.3.1.2.3.3.2 Development of fracture network model

8.3.1.3.1.1 Ground-water chemistry model

8.3.1.3.2.1 Mineralogy, petrology, and chemistry of transport pathways

8.3.1.3.2.1.1 Petrologic stratigraphy of the Topopah Spring Member 
8.3.1.3.2.1.2 Mineral distributions between the host rock and the accessible environment

8.3.1.3.2.1.3 Fracture mineralogy

8.3.1.3.2.2.1 History of mineralogic and geochemical alteration of Yucca Mountain

8.3.1.3.2.2.2 Smectite, zeolite, manganese minerals, glass dehydration, and transformation

8.3.1.3.4.1 Batch sorption studies

8.3.1.3.4.1.1 Batch sorption measurements as a function of solid phase composition

8.3.1.3.4.2 Biological sorption and transport

8.3.1.3.5.1.1 Solubility measurements

8.3.1.3.6.1.1 Crushed tuff column experiments

8.3.1.3.6.2.1 Uptake of radionuclides on rock beakers in a saturated system

8.3.1.3.6.2.2 Diffusion through a saturated tuff slab

8.3.1.4.1.2 Integration of geophysical activities

8.3.1.4.2.1.1 Surface and subsurface stratigraphic studies of the host rock and surrounding units

8.3.1.4.2.1.2 Surface-based geophysical surveys

8.3.1.4.2.1.3 Borehole geophysical surveys

8.3.1.4.2.1.4 Petrophysical properties testing

8.3.1.4.2.1.5 Magnetic properties and stratigraphic correlations

8.3.1.4.2.1.6 Integration of geophysical activities

8.3.1.4.2.2 Characterization of the structural features within the site area

8.3.1.4.2.2.1 Geologic mapping of zonal features in the Paintbrush Tuff 
8.3.1.4.2.2.2 Surface-fracture network studies

8.3.1.4.2.2.3 Borehole evaluation of faults and fractures

8.3.1.4.2.2.4 Geologic mapping of the Exploratory studifs Facility

8.3.1.4.2.2.5 Seismic tomography/vertical seismic profiling

8.3.1.4.2.3.1 Development of a three-dimensional geologic model of the site area

8.3.1.4.3.1 Systematic acquisition of site-specific subsurface irformation

8.3.1.4.3.1.1 Systematic drilling program

8.3.1.5.1.1.1 Synoptic characterization of regional climate

8.3.1.5.1.2.1 Paleontologic analyses

8.3.1.5.1.2.2 Analysis of the stratigraphy-sedimentology of marsh lacustrine, and playa deposits

8.3.1.5.1.3.1 Analysis of pack rat middens

8.3.1.5.1.3.3 Determination of vegetation-climate relationships

8.3.1.5.1.4.1 Modeling of soil properties in the Yucca Mountain region

8.3.1.5.1.4.2 Surficial deposits mapping of the Yucca Mountain area

8.3.1.5.1.4.3 Eolian history of the Yucca Mountain region

8.3.1.5.1.5.1 Paleoclimate-paleoenvironmental synthesis

8.3.1.5.2.1.1 Regional paleoflood evaluation

8.3.1.5.2.1.2 Quaternary unsaturated zone hydrochemical analysis

8.3.1.5.2.1.3 Evaluation of past discharge areas

8.3.1.5.2.1.4 Analog recharge studies 
8.3.1.5.2.1.5 Studies of calcite and opaline silica vein deposits

8.3.1.6.1.1.1 Development of a geomorphic map of Yucca Mountain

8.3.1.6.1.1.2 Analysis of the downcutting history of Fortymile Wash and its tributaries

8.3.1.6.1.1.3 An analysis of hillslope erosion at Yucca Mountain

8.3.1.6.2.1.1 Synthesis and data evaluation of impact of future climatic conditions on locations and rates of erosion

8.3.1.6.3.1.1 Synthesis and data evaluation of the impact of future uplift or subsidence and faulting on erosion at Yucca Mountain and vicinity

8.3.1.8.1.1.3 Presence of magma bodies in the vicinity of the site

8.3.1.8.1.2.1 Eruptive effects

8.3.1.8.3.2.2 Assessment of the effects of igneous intrusions on water-table elevations

8.3.1.8.3.2.5 Effects of faulting on water-table elevation

8.3.1.8.5.1.2 Geochronology studies

8.3.1.8.5.1.3 Field geologic studies

8.3.1.8.5.1.4 Geochemistry of scoria sequences

8.3.1.8.5.1.5 Geochemical cycles of basaltic volcanic fields

8.3.1.8.5.2.1 Evaluation of depth of curie temperature isotherm

8.3.1.8.5.2.3 Heat flow at Yucca Mountain and evaluation of regional ambient heat flow and local heat flow anomalies

8.3.1.9.2.1.1 Geochemical assessment of Yucca Mountain in relation to the potential for mineralization

8.3.1.9.2.1.4 Assessment of hydrocarbon resources at and near the site 
8.3.1.9.2.2.1 Projected trends in local and regional groundwater development, and estimated withdrawal rates in southern Nevada, proximal to Yucca Mountain

8.3.1.12.2.1.1 Site meteorological monitoring program

8.3.1.14.2.1.1 Site reconnaissance

8.3.1.14.2.1.2 Preliminary and detailed exploration

8.3.1.14.2.2.1 Physical property and index laboratory tests

8.3.1.14.2.2.2 Mechanical and dynamic laboratory property tests

8.3.1.14.2.3 Field tests and characterization measurements

8.3.1.14.2.3.1 Physical property field tests and characterization measurements

8.3.1.14.2.3.2 Mechanical property field tests

8.3.1.14.2.3.3 Geophysical field measurements

8.3.1.15.1.1.1 Density and porosity characterization

8.3.1.15.1.1.3 Thermal conductivity characterization

8.3.1.15.1.2.1 Thermal expansion characterization

8.3.1.15.1.3 Laboratory determination of mechanical properties of intact rock

8.3.1.15.1.3.1 Compressive mechanical properties of intact rock at baseline experiment conditions

8.3.1.15.1.3.2 Effects of variable environmental conditions on mechanical properties

8.3.1.15.1.4 Laboratory determination of the mechanical properties of fractures

8.3.1.15.1.7.1 Plate loading tests

8.3.1.15.1.8.1 Evaluation of mining methods

8.3.1.15.2.1.2 Overcore stress experiments in the exploratory studies facility 
8.3.1.15.2.2.1 Surface-based evaluation of ambient thermal conditions

8.3.1.16.1.1.1 Site flood and debris hazards studies

8.3.1.16.2.1.4 Identification and evaluation of potential effects of repository related withdrawals on the local

flow system at Yucca Mountain, Nevada

8.3.1.17.2.1.2 Assess the potential for displacement on faults that intersect underground facilities

8.3.1.17.3.3.2 Select or develop empirical models for ground motion from underground nuclear explosions

8.3.1.17.3.5.1 Identify controlling seismic events

8.3.1.17.3.5.2 Characterize ground motion from the controlling seismic events

8.3.1.17.3.6.2 Evaluate ground motion probabilities

8.3.1.17.4.1.1 Compile historical earthquake record

8.3.1.17.4.1.2 Monitor current seismicity

8.3.1.17.4.1.3 Evaluate potential for induced seismicity at the site

8.3.1.17.4.2 Location and recency of faulting near prospective surface facilities

8.3.1.17.4.2.1 Identify appropriate trench locations in Midway Valley

8.3.1.17.4.3.1 Conduct and evaluate deep geophysical surveys in an east-west transect crossing the Furnace Creek fault zone, Yucca Mountain, and the Walker Lane

8.3.1.17.4.3.2 Evaluate Quaternary faults within $100 \mathrm{~km}$ of Yucca Mountain

8.3.1.17.4.3.4 Evaluate the Bare Mountain fault zone

8.3.1.17.4.3.5 Evaluate structural domains and characterize the Yucca Mountain region with respect to regional patterns of faults and fractures 
8.3.1.17.4.4.1 Evaluate the Rock Valley fault system

8.3.1.17.4.5.1 Evaluate the significance of the Miocene-Paleozoic contact in the Calico Hills area to detachment

faulting within the site area

8.3.1.17.4.5.2 Evaluate postulated detachment faults in the Beatty-Bare Mountain area

8.3.1.17.4.6.1 Evaluate Quaternary geology and potential Quaternary faults at Yucca Mountain

8.3.1.17.4.6.2 Evaluate age and recurrence of movement on suspected and known Quaternary faults

8.3.1.17.4.7.1 Evaluate intermediate depth $(2$ to $3 \mathrm{~km}$ ) reflection and refraction methods and plan potential application of these methods within the site area

8.3.1.17.4.7.2 Detailed gravity survey of the site area

8.3.1.17.4.7.3 Detailed aeromagnetic survey of the site area

8.3.1.17.4.7.4 Detailed ground magnetic survey of specific features within the site area

8.3.1.17.4.7.5 Evaluate surface geoelectric methods and plan potential application of these methods within the site area

8.3.1.17.4.7.8 Evaluate shallow seismic reflection (mini-sosie) methods and, if appropriate, conduct surveys of selected structures at and proximal to the site area

8.3.1.17.4.8.1 Evaluate present stress field within site area

8.3.1.17.4.8.2 Evaluate and test shallow borehole hydrofrac and triaxial strain recovery methods for the determination of in situ stress and, if appropriate, plan potential application of these methods within and proximal to the site

8.3.1.17.4.9.1 Evaluate age and extent of tectonically stable areas at and near Yucca Mountain

8.3.1.17.4.10.1 Relevel base-station network, Yucca Mountain and vicinity 
8.3.1.17.4.10.2 Survey selected base stations, Yucca Mountain and vicinity, using global positioning satellite

8.3.1.17.4.10.3 Analyze existing releveling data, Yucca Mountain and vicinity

8.3.1.17.4.12.1 Evaluate tectonic processes and tectonic stability at the site

8.3.2.4.1.1 Design activity to verify access and drift usability

8.3.5.4.1.1 Refinement of site data parameters required for Issue 2.2

8.3.5.12.1.1 Application of results

8.3.5.10.2.1 Characterization of the spent fuel waste form

8.3.5.10.2.2 Characterization of the glass waste form

8.3.5.10.3.2 Develop geochemical speciation and reaction model

8.3.5.10.5.1 Determine radionuclide transport parameters

8.3.5.10.5.2 Radionuclide transport modeling in the near-field waste package environment

8.3.5.12.2.1 Model development

8.3.5.12.2.1.1 Development of a theoretical framework for calculational models

8.3.5.12.2.2 Verification and validation 


\section{APPENDIX B}

GEOLOGIC AND ENGINEERING MATERIALS: BIBLIOGRAPHY OF CBEMICAL SPECIES (GEMBOCHS) SPECIES AND DATA TYPES

COMPOSITIONAL DATA FOR MINERALS, GASES, OR AOUEOUS SPECIES

Elemental Composition

Common Name

REACTION DATA FOR AOUEOUS DISSOCIATION OF MINERALS, GASES, OR AOUEOUS SPECIES

Reaction Stoichiometry

Equilibrium Constants

Pressure, Temperature Conditions

Standard Molal Gibbs Free Energies of Reaction

Standard Molal Enthalpies of Reaction

Standard Molal Entropies of Reaction

Standard Molal Volumes of Reaction

Standard Molal Heat Capacities of Reaction

Parameter Units

Literature References

THERMODYNAMIC DATA FOR MINERALS

Standard Molal Gibbs Free Energy of Formation

Standard Molal Enthalpy of Formation

Standard Molal Entropy at Reference Pressure (Pr) and Temperature (Tr)

Standard Molal Volume at $\mathrm{Pr}, \mathrm{Tr}$

Standard Molal Heat Capacity at Pr, Tr

Molecular Weight

Heat Capacity Coefficients

Temperature Limits on Heat Capacity Coefficients

Standard Molal Enthalpy of Transition

Standard Molal Entropy of Transition

Standard Molal Volume of Transition

Clapeyron Slope

Parameter Units

Literature References 


\section{THERMODYNAMIC DATA FOR GASES}

Standard Molal Gibbs Free Energy of Formation

Standard Molal Enthalpy of Formation

Standard Molal Entropy at Pr, Tr

Standard Molal Volume at Pr, Tr

Standard Molal Heat Capacity at Pr, Tr

Molecular Weight

Heat Capacity Coefficients

Temperature Limits on Heat Capacity Coefficients

Parameter Units

Literature References

\section{THERMODYNAMIC DATA FOR AOUEOUS SPECIES}

Standard Molal Gibbs Free Energy of Formation

Standard Molal Enthalpy of Formation

Standard Molal Entropy at Pr, Tr

standard Molal Volume at Pr, Tr

Standard Molal Heat Capacity at Pr, Tr

Molecular Weight

Equation-of-State Coefficients

Debye-Huckel Parameters

Ionic Charge

Electronic Entropy

Parameter Units

Literature References 


\section{APPENDIX C}

GEMBOCES MODIFICATIONS AND ADDITIONS: 18t QOARTER, FY 1994

During the first quarter of FY 1994, several important additions and modifications were made to the GEMBOCHS thermodynamic data base, and significant progress was realized in developing the next-generation GEMBOCHS software library.

Recent updates to the data base itself have focused on improving its flexibility with regard to representing organic systems, and enhancing its breadth to provide improved representation of actinide-bearing systems. These updates include:

- Complete revision of the set of basis and auxiliary-basis carbon, nitrogen, and sulfur species used to represent aqueous dissociation of organic compounds and aqueous species. This update has improved significantly the accuracy and flexibility of $\mathrm{EQ} 3 / 6$ speciation and mass transfer models of organic and inorganic/organic systems.

- Initiation of a reconnaissance and review of recently published thermodynamic data for Technetium, Neptunium, Plutonium, and Americium species. As needed and where appropriate, these data are being used to augment those already in GEMBOCHS until publication of the NEA-TDB critical reviews of the chemical thermodynamics of these species. (These reviews, which will appear as separate volumes in the series begun by the corresponding Uranium compilation [Grenthe et al., 1992], are in progress, but even the most advanced of these is unlikely to reach publication before 1996.) During the first quarter of FY 1994, an extensive literature search was initiated, and aqueous dissociation constants reported by Palmer, Silva, and Miller (1992) for approximately 300 aqueous $\mathrm{Np}, \mathrm{Pu}$, and Am complexes were incorporated.

- Incorporation of additional thermodynamic data for antimony compounds and aqueous species, reported from a variety of literature sources. This update improves considerably the ability to represent the thermodynamic behavior of antimonybearing systems. 
Recent work on the GEMBOCHS software library has focused on developing mouse-driven (Ingres Windows/4GL) application codes that will ultimately replace the existing function-key-driven (FORTRAN77-EQUEL) analogs, facet and jewel, which represent the two fundamental user interfaces with GEMBOCHS data. In addition, the entire GEMBOCHS system is currently being ported to an upgraded hardware platform. Specifically, this included:

- Continuing the development of a Windows/4GL version of jewel. In essence, this program interfaces user specifications, GEMBOCHS data, and various thermodynamic extrapolation algorithms to facilitate point-and-click generation of customized thermodynamic data files on the basis of preexisting data sets, species subsets, or bulk composition of the chemical system to be modeled. During the first quarter of $F Y$ 1994, continued local use of and numerous refinements to the program rendered its predecessor (the function-key driven version) nearly obsolete. During the second quarter of FY 1994, the user's manual will be completed, and the mouse-driven jewel will be used exclusively.

- Initiating the development of a Window/4GL version of facet. This program facilitates point-and-click review, revision, deletion, and addition of GEMBOCHS data. During the first quarter of FY 1994, most top-level routines (and many primitives) were completed, as was a significant amount of testing.

- Initiating the transfer of the GEMBOCHS data base and software library from its dedicated Sun SPARCstation2 to a new dedicated SPARCstation10/41. This hardware upgrade will result in dramatically improved performance for each data base and software module of the GEMBOCHS system. During December 1993, the new SPARC10/41 was set-up and Ingres 6.4104, jewel, facet, and cngbochs were all ported to this platform. 


\section{APPENDIX D}

GENISES ADDITIONS: 18t QUARTER, FY 1994

DATA TRACKING NO. DATA ITEM DESCRIPTION

$\begin{array}{ll}\text { LAO00000000053.001 } & \begin{array}{l}\text { ACTINIDE (IV) AND ACTINIDE (VI) CARBONATE } \\ \text { SPECIATION STUDIES BY PAS AND NMR } \\ \text { SPECTROSCOPIES }\end{array} \\ \text { LA000000000023.002 } & \begin{array}{l}\text { MINERALOGY AND CLINOPTILOLITE K/AR RESULTS } \\ \text { FROM YUCCA MOUNTAIN, NEVADA, USA: A POTENTIAL } \\ \text { HIGH-LEVEL RADIOACTIVE WASTE REPOSITORY SITE }\end{array} \\ \text { SNSAND80145300.000 } & \begin{array}{l}\text { ROCK MECHANICS PROPERTIES OF VOLCANIC TUFFS } \\ \text { FROM THE NEVADA TEST SITE }\end{array} \\ \text { LA000000000017.002 } & \begin{array}{l}\text { DEHYDRATION AND REHYDRATION OF A TUFF } \\ \text { VITROPHYRE }\end{array} \\ \text { LA000000000034.002 } & \begin{array}{l}\text { DIFFUSION OF SORBING AND NON-SORBING } \\ \text { RADIONUCLIDES }\end{array}\end{array}$

$D-1$ 



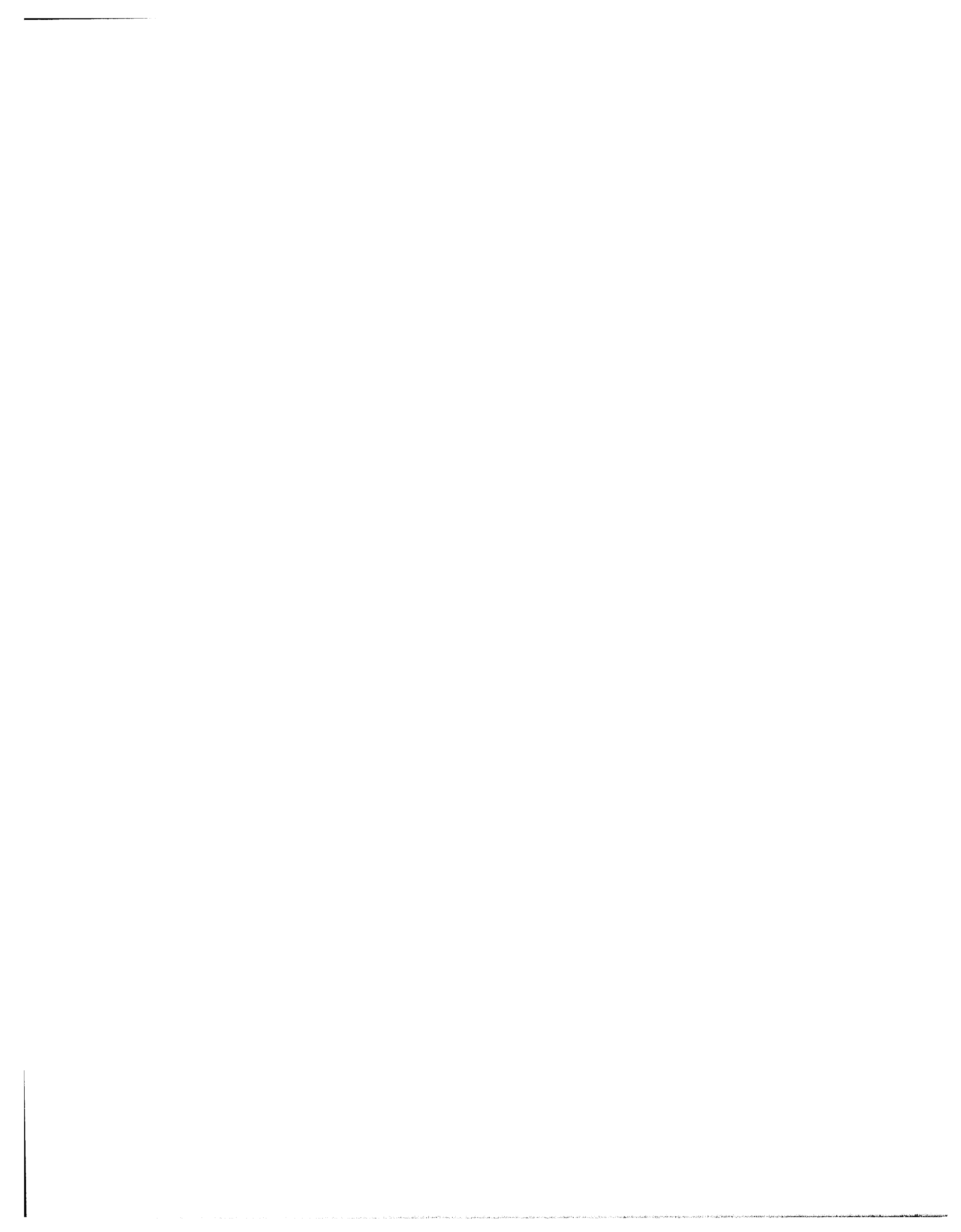

